\title{
Verantwoord beleggen: de hype voorbij?
}

Citation for published version (APA):

Bauer, R. M. M. J. (2008). Verantwoord beleggen: de hype voorbij? Maastricht University. https://doi.org/10.26481/spe.20080530rb

Document status and date:

Published: 30/05/2008

DOI:

10.26481/spe.20080530rb

Document Version:

Publisher's PDF, also known as Version of record

\section{Please check the document version of this publication:}

- A submitted manuscript is the version of the article upon submission and before peer-review. There can be important differences between the submitted version and the official published version of record.

People interested in the research are advised to contact the author for the final version of the publication, or visit the DOI to the publisher's website.

- The final author version and the galley proof are versions of the publication after peer review.

- The final published version features the final layout of the paper including the volume, issue and page numbers.

Link to publication

\footnotetext{
General rights rights.

- You may freely distribute the URL identifying the publication in the public portal. please follow below link for the End User Agreement:

www.umlib.nl/taverne-license

Take down policy

If you believe that this document breaches copyright please contact us at:

repository@maastrichtuniversity.nl

providing details and we will investigate your claim.
}

Copyright and moral rights for the publications made accessible in the public portal are retained by the authors and/or other copyright owners and it is a condition of accessing publications that users recognise and abide by the legal requirements associated with these

- Users may download and print one copy of any publication from the public portal for the purpose of private study or research.

- You may not further distribute the material or use it for any profit-making activity or commercial gain

If the publication is distributed under the terms of Article $25 \mathrm{fa}$ of the Dutch Copyright Act, indicated by the "Taverne" license above, 


\section{Universiteit Maastricht}

dr. Rob Bauer

\section{Verantwoord beleggen: de hype voorbij?}

\section{vin}

cbătalla,

hoofdstad van

I Faculty of Economics and Business Administration cet. 2. ecce 2.

cca, eccam,

ccé, interi.

1. (om de aandacht ziedaar e. ti heb je, kijk, of nos; e. $t$ daar he litteras; ecce me of het beric accipe litterar krijg je op eens voorbeel inz. in een ope. aliud. honvizen, ook hot daa. leven) verb 

Verantwoord beleggen: de hype voorbij? 


\section{Colofon}

Ontwerp en print: Océ Business Services, Maastricht

ISBN: 978-90-5681-284-3

NUR: 781

Alle rechten voorbehouden. Niets uit deze uitgave mag worden verveelvoudigd, opgeslagen in een geautomatiseerd gegevensbestand of openbaar gemaakt worden, zonder voorafgaande schriftelijke toestemming van de auteur of uitgever. 


\section{Verantwoord beleggen: de hype voorbij?}

\section{Rede}

in verkorte vorm uitgesproken ter gelegenheid van de aanvaarding van het ambt van hoogleraar Institutionele Beleggers aan de Faculteit der Economische Wetenschappen en Bedrijfskunde van de Universiteit Maastricht

op vrijdag 30 mei 2008

door

dr. Rob Bauer

Maastricht University 

Mijnheer de Rector Magnificus, lieve familie en vrienden, geachte toehoorders

\section{Inleiding}

In oktober 2004 werd ik benoemd tot hoogleraar Institutionele Beleggers aan de Universiteit Maastricht. Bij het aanstellingsgesprek met Gerald Mols, Rector Magnificus en Jo Ritzen, voorzitter van het College van Bestuur, beloofde ik heilig mijn oratie binnen afzienbare tijd in te plannen. Nu zijn de begrippen "heilig" en "afzienbaar" behoorlijk rekbaar, maar dat ik deze rede ruim drie jaar na mijn benoeming zou houden, is niet wat beide heren op dat moment van mij verwachtten. Ik wil hiervoor mijn welgemeende excuses aanbieden. Ik ben ook dankbaar voor het uitblijven van gepaste druk om mij aan te sporen deze rede spoediger te houden. Sterker nog: door als College te investeren in het onderzoeksinstituut The European Centre for Corporate Engagement (ECCE) heeft $u$ het uitstel voor een deel veroorzaakt. Mijn grootste excuses gaan echter naar mijn recent overleden grootmoeder Maria Ploem. Zij was nog gezond en wel op het tijdstip van mijn benoeming en verlangde regelmatig naar deze feestelijke gebeurtenis en vooral het diner met enkele vooraanstaande hoogleraren. Zij heeft dit helaas niet meer mogen meemaken. Oma, hopelijk kan je op de een of andere wijze deelnemen aan deze heuglijke dag.

Maar waarom stelde ik de oratie eigenlijk steeds weer uit? Was het een vorm van gemakzucht of waren er goede redenen om de datum steeds verder vooruit te schuiven? Bijvoorbeeld het opvoeden van drie jonge kinderen en alles wat daarmee gepaard gaat? Of het oprichten van ECCE en de start van een prestigieus internationaal onderzoeksprogramma op het gebied van verantwoord beleggen? Of wellicht het opstarten van een opleidingsinstituut voor professionals in de pensioen- en verzekeringssector? Of toch de onmogelijke combinatie van een universitaire aanstelling als hoogleraar en een drukke baan in het bedrijfsleven? De alledaagse beslommeringen in werk en privé zorgden voor genoeg afleiding, maar ook voor een excuus om de oratie steeds maar weer uit te stellen. Alle genoemde redenen verklaren een deel van de vertraging, maar de echte oorzaak ligt veel dieper verborgen in mijn bewustzijn. De prangende vraag is namelijk: waarom hap ik meteen toe als er weer een nieuw en interessant onderzoeksproject langskomt? 
Lijd ik mogelijk aan dezelfde ziekte waaraan vele leden van het bestuur van beursgenoteerde ondernemingen lijden? Heb ook ik te veel aandacht voor korte termijn resultaten en investeer ik te weinig in projecten voor de lange termijn? Niet gehinderd door de perverse beloningsstructuur van het bedrijfsleven, realiseerde ik mij gelukkig net op tijd dat ik mijn rede echt niet meer kon uitstellen. De korte termijn voordelen zouden spoedig niet meer opwegen tegen de lange termijn nadelen. Mijn reputatie als hoogleraar zou bezoedeld raken. Grote onderzoeksprojecten zouden aan mijn neus voorbijgaan, omdat je met Rob Bauer uit Maastricht geen goede afspraken kunt maken. Uiteindelijk zou ook mijn vernieuwingskracht slinken. Maar nu is het dan zo ver. Ik ga mijn rede houden en sterker nog: het boekje is gedrukt en ligt voor u klaar.

\section{De hype voorbij?}

Velen onder $u$ zal het niet verbazen dat ik vandaag het onderwerp verantwoord beleggen heb gekozen. In 2001 maakte ik voor het eerst kennis met het thema. ABP Vermogensbeheer was een experiment gestart met het opzetten van een duurzame beleggingsportefeuille. Als ervaren portefeuillemanager en gepromoveerde onderzoeker had ik dezelfde primaire reactie als veel tegenstanders die ik zal citeren in deze rede: "principes kosten geld". Ik was op dat moment net teruggekeerd als parttime wetenschapper naar de UM. Tijdens een brainstormsessie met Rogér Otten en Kees Koedijk is in feite het idee geboren voor een studie naar duurzame beleggingsfondsen. Het artikel werd onverwacht vaak gedownload en kreeg al meteen veel aandacht in de landelijke en internationale pers. De NRC kopte bijvoorbeeld "Geitenwollensokkenfondsen leren beleggen". Dit was voor mij een goede stimulans om het verschijnsel verantwoord beleggen eens goed onder de loep te nemen.

Maar ook verantwoord beleggen is een rekbaar begrip. Heeft het vooral te maken met de integratie van elementen van maatschappelijk verantwoord ondernemen in een beleggingsproces? Of omvat de term verantwoord beleggen een breder scala aan onderwerpen die een financieel econoom stof tot nadenken geven? Denk bijvoorbeeld aan de morele verplichting van institutionele beleggers als beleggingsfondsen, pensioenfondsen en verzekeraars om als een goed rentmeester met de aan hun toevertrouwde vermogens van klanten om te gaan? De 
recente ophef over woekerpolissen in de verzekeringsmarkt en de opzwellende discussie over de kostenstructuur en beleggingsprestaties van beleggingsfondsen geven duidelijk aan dat er nog wel een balletje kan worden opgeworpen over de maatschappelijke verantwoordelijkheid van financiële instellingen in het algemeen. En dit zijn vaak dezelfde instellingen die producten aanbieden op het gebied van verantwoord beleggen aan het grote publiek. In het grootste deel van deze rede zal ik mij beperken tot verantwoord beleggen in enge zin, dus als verlengstuk van maatschappelijk verantwoord ondernemen. Aan het einde van mijn betoog zal ik het begrip verantwoord beleggen nog iets ruimer interpreteren. Zijn $u$ en ik als eenvoudige burgers opgewassen tegen goedgeëquipeerde financiële instellingen? Leidt deze asymmetrie wellicht tot onverantwoorde producten en proposities?

Wetenschappers hebben de luxe om hun onderzoekswereld voor een deel zelf te definiëren en daar maak ik nu ook even gretig gebruik van. Als financieel econoom richt ik mij uitdrukkelijk niet op de ethische motieven van pensioenfondsen of de relatie van dergelijke beweegredenen met de identiteit van het fonds en zijn deelnemers. Wel ben ik zeer benieuwd of de keuzes die pensioenfondsen uiteindelijk maken naar verwachting invloed hebben op de rendementen en risico's van de beleggingsportefeuille van het fonds. Ik richt mij in deze rede grotendeels op een bepaald type institutionele belegger: het pensioenfonds. Ook dat zal u niet verbazen vanwege mijn achtergrond bij het ABP. Maar er zijn ook andere goede redenen om dit type financiële instelling in deze context nader onder de loep te nemen. In 2007 hebben Nederlandse pensioenfondsen nadrukkelijk te maken gehad met maatschappelijke druk op het gebied van verantwoord beleggen Enkele grote pensioenfondsen werden in een uitzending van Zembla ("Het Clusterbomgevoel") geconfronteerd met hun posities in aandelen van ondernemingen die clusterbommen en landmijnen produceren. Het gevolg was maatschappelijke verontwaardiging en veel negatieve aandacht en onbegrip in de pers. Pensioenfondsen zijn overigens bijzondere financiële instellingen. In tegenstelling tot de meeste banken en verzekeraars zijn het non-profit instellingen. De besturen van pensioenfondsen zijn een blauwdruk van Nederland polderland. Deze maatschappelijke afspiegeling maakt het thema verantwoord beleggen voor pensioenfondsen extra interessant. 
De rode draad in mijn betoog is hoe een financieel-economische wetenschapper kan bijdragen aan de objectivering van het maatschappelijke debat over verantwoord beleggen. De noodzaak hiervan blijkt regelmatig uit de vaak ongefundeerde en ongenuanceerde uitlatingen van voor- en tegenstanders in de media. Een goed voorbeeld hiervan zijn de woorden van Giuseppe van der Helm, voorzitter van de Vereniging van Beleggers in Duurzame Ontwikkeling (VBDO), in de bewuste documentaire van Zembla:

"Het is een misverstand dat duurzaam beleggen leidt tot minder rendement. ... Uit onderzoek blijkt eerder dat duurzaam beleggen meer rendement oplevert dan niet-duurzaam beleggen."

Zonder blikken of blozen wordt in Zembla door de voorzitter van de VBDO gesteld dat onderzoek heeft aangetoond dat duurzaam beleggen meer rendement oplevert ${ }^{2}$. Van een gecoördineerde wetenschappelijke onderzoeksagenda is echter nauwelijks sprake en evenmin van eenduidige onderzoeksresultaten. Het is mij dus een groot raadsel waar van der Helm zijn conclusie op baseert. Ik kan mij niet aan de indruk onttrekken dat de wens de vader is van de gedachte. Wetenschappers zijn in toenemende mate geïnteresseerd in de toegevoegde waarde van maatschappelijkverantwoordondernemenen degevolgenvoorbeleggers in die ondernemingen. Sporadisch worden studies gepubliceerd die het positieve verband tussen duurzaamheid en rendementen bevestigen, maar al te ferme conclusies kunnen tot op heden niet getrokken worden. Veel onderzoeken zijn puur empirisch georiënteerd en missen een solide theoretische basis voor de hypotheses die worden getoetst. Bovendien is er sprake van het bekende "file drawer" probleem³. Studies met positieve resultaten krijgen meer aandacht in de media en maken een grotere kans op publicatie in gerenommeerde tijdschriften. De overige studies verdwijnen in de bureaula met als gevolg dat ik ze niet kan citeren in dit betoog. Dat kan een scheef beeld opleveren van de algemene status van empirisch onderzoek naar de relatie tussen verantwoord beleggen en rendement.

Frappant is dat de lobby voor verantwoord beleggen soms ook kan doordringen in wetenschappelijke tijdschriften. Friend White (2005) schrijft in een artikel in the Journal of Investing ${ }^{4}$ : 
"Adding the next layer, simple exclusions such as those practiced by almost all Dutch pension funds that screen companies involved in Tobacco, or operating in Myanmar, for example, bring the assets under management to $€ 218$ billion."

De stelling van Friend White (2005) dat vrijwel alle Nederlandse pensioenfondsen ondernemingen die actief zijn in de tabaksindustrie uitsluiten, is volledig uit de lucht gegrepen. Een onafhankelijke en objectieve blik op de zaak is dus hard nodig. In de afgelopen jaren zijn er wereldwijd enkele nieuwe initiatieven ontplooid waarin wetenschappers in samenwerking met financiële instellingen op zoek gaan naar antwoorden. ECCE is daar een goed voorbeeld van.

Objectief onderzoek naar verantwoord beleggen raakt de kern van financiële markten: vertrouwen. Vertrouwen is een belangrijk ingrediënt voor de bank die geld leent aan een onderneming, maar ook voor een particuliere belegger die een deel van zijn vermogen belegt via beleggingsfondsen of een werknemer die zijn pensioen opbouwt bij een verzekeringsmaatschappij of pensioenfonds. Zonder vertrouwen kunnen financiële markten niet naar behoren functioneren. De impact van de boekhoudschandalen bij Enron en Ahold en de recente kredietcrisis zijn daar goede voorbeelden van. Het is daarom zeer begrijpelijk dat de maatschappij steeds meer transparantie eist over de gang van zaken binnen ondernemingen. Een voorbeeld daarvan is openheid over de beloning van bestuurders. De bestuursvoorzitter van Fortis, Jean-Paul Votron, zegt volledig transparant te willen zijn in de discussie die is ontstaan over zijn beloning 5 .

"Ik heb begrip voor het debat en we zullen er open over zijn."

Maar vervolgens slaat Votron in hetzelfde interview de plank wat mij betreft volledig mis:

"Maar prettig vind ik het niet. Ik begrijp ook niet waarom alleen de salarissen van CEO's ter discussie staan en niet van bijvoorbeeld tennissers".

Hoewel ik een beloning van enkele duizenden euro's per voetstap voor een tennisser gevoelsmatig ook wat aan de hoge kant acht, is er een fundamenteel verschil tussen een toptennisser en een CEO van een beursgenoteerde onderneming. Een toptennisser is tegelijkertijd 
bestuursvoorzitter, manager, werknemer en aandeelhouder van zijn eigen onderneming. De voorzitter van het bestuur van een grote, beursgenoteerde vennootschap is in dienst getreden als werknemer en moet verantwoording afleggen aan aandeelhouders en andere belanghebbenden in enge of ruime zin. Daarom spreken we ook van salaris voor de bestuurder. Zolang bestuursvoorzitters zich publiekelijk op deze wijze uiten, is hun vertrouwensrelatie met aandeelhouders en overige belanghebbenden nog flink voor verbetering vatbaar.

In de titel van mijn oratie neem ik doelbewust de zinsnede "de hype voorbij?" op. Is verantwoord beleggen een voorbeeld van een van de vele tijdelijke trends op financiële markten en als zodanig een nieuwe uiting van het fenomeen kuddegedrag? Of heeft de hype de potentie om bij te dragen aan een ongekende verduurzaming van financiële markten? In mijn rede wil ik deze vragen oppakken door objectief te beschouwen welke financiële gevolgen verantwoord beleggen kan hebben voor institutionele beleggers. Om de problematiek goed in te leiden zal ik het verschijnsel verantwoord beleggen eerst goed definiëren en inbedden in de context van institutionele beleggers. Vervolgens bespreek ik de twee basisvormen van verantwoord beleggen: uitsluiting op grond van ethische motieven, emotie of smaak, en insluiting door het integreren van extrafinanciële informatie in het reguliere beleggingsproces. Bij de bespreking van uitsluiting zal ik de nadruk leggen op de vraag of het toepassen van deze vorm van verantwoord beleggen op gespannen voet staat met de algemene opdracht van institutionele beleggers en pensioenfondsen in het bijzonder. De paragraaf over extrafinanciële informatie stelt de vraag centraal of maatschappelijk rendement en financieel rendement kunnen samengaan. Uit de analyse van uitsluiting en insluiting zal blijken dat veel vragen onbeantwoord blijven en dat additioneel wetenschappelijk onderzoek in aanpalende domeinen gewenst is. Toch kan ik Nederlandse pensioenfondsbesturen alvast geruststellen: een beperkt uitsluitingsbeleid hoeft geen negatieve gevolgen te hebben voor hun aandelenportefeuilles en er zijn aanwijzingen dat insluiting zelfs waarde kan toevoegen.

\section{Verantwoord beleggen}

Ik hanteer in mijn betoog de volgende definitie voor verantwoord beleggen: beleggen op grond van overwegingen met betrekking tot milieubeleid, sociaal beleid, ethiek en de kwaliteit van het 
ondernemingsbestuur van ondernemingen en/of de beïnvloeding van ondernemingen. In de Angelsaksisch georiënteerde financiële wereld wordt vandaag de dag gesproken over zogenaamde "Environmental" (E), "Social" (S) en "Governance" (G) factoren: ESG-factoren. Integratie van deze factoren in het beleggingsbeleid heet dan in beleggerjargon verantwoord beleggen.

Verantwoord beleggen is geen nieuwfenomeen.DeQuakersindeVerenigde Staten sloten al in de achttiende eeuw beleggingen in de slavenhandel of de productie van wapentuig op grond van ethische uitgangspunten categorisch uit. De Methodistenkerk in het Verenigd Koninkrijk startte in 1920 met het consequent uitsluiten van ondernemingen uit de alcoholen tabaksindustrie. Institutionele beleggers in de Verenigde Staten, waaronder enkele grote pensioenfondsen, spraken ondernemingen tijdens de oorlog in Vietnam aan op hun betrokkenheid bij de productie van napalm. lets minder lang geleden is het uitsluiten van beleggingen in Zuid-Afrika tijdens het apartheidsregime, zie Grossman en Sharpe (1986) en Munnell (2007) voor meer details over de historie. Deze voorbeelden zijn in wezen allemaal vormen van uitsluitingsbeleid, de verschijningsvorm van verantwoord beleggen die het meest in de publieke belangstelling staat. Uitsluiting doet vooral opgeld in de Verenigde Staten waar het niet beleggen in zogenaamde "sin stocks" in sommige kringen gemeengoed is. Sin stocks ("zonde aandelen") zijn aandelen in ondernemingen die betrokken zijn bij de productie van tabak, alcohol, wapens, porno of in ondernemingen die nauwe banden hebben met de gokindustrie. Je zou kunnen zeggen: ondernemingen die niet passen bij de sociale normen van een deel van de Amerikaanse bevolking. Deze vorm van beleggen werd in het begin van de jaren zeventig redelijk populair onder de term "Socially Responsible Investing" (SRI). In Nederland gebruiken we vaak de term duurzaam beleggen.

De term verantwoord beleggen kwam voor het eerst in zwang toen de Verenigde Naties (VN) in 2005 een aantal grote institutionele beleggers uitnodigde om gezamenlijk de zogenaamde "Principles for Responsible Investment" (de PRI) te ontwikkelen, letterlijk vertaald de beginselen voor verantwoord beleggen. De zes PRI beginselen reflecteren de kernwaarden van de deelnemende financiële instellingen die allen een aanzienlijk belegd vermogen en een lange beleggingshorizon met elkaar gemeen hebben. PGGM, een van de initiatiefnemers, heeft op haar website $^{6}$ een vrijwel letterlijke Nederlandse vertaling van de PRI 
beginselen gepubliceerd. Het eerste en meest in het oog springende beginsel luidt:

"PGGM belooft met de ondertekening van de PRI om ESG-factoren nadrukkelijk te integreren in het beleggingsproces en de besluitvorming daaromtrent".

Bovendien beloven de ondertekenaars van de PRI om op te treden als actieve aandeelhouders die ESG-factoren meenemen in hun stemgedrag op aandeel houdersvergaderingen. Ook wordt transparantie gevraagd van ondernemingen op het gebied van ESG onderwerpen en bieden de beleggers zelf transparantie over hoe de PRI daadwerkelijk geïmplementeerd zijn.

Op dit moment, aldus de website van de VN, heeft een grote groep institutionele beleggers en aanverwante ondernemingen uit de financiële sector de PRI ondertekend. Deze instellingen, waaronder grote banken, vermogensbeheerders, pensioenfondsen en verzekeraars, beheren gezamenlijk maar liefst 13 triljoen dollar vermogen. De VN pronkt er opzichtig mee op haar website, maar hoe implementeren deze beleggers de beginselen in de praktijk? Enkele maanden voor de bewuste Zembla documentaire onderzocht mijn collega professor Harry Hummels of Nederlandse pensioenfondsen een expliciet gedocumenteerd beleid hebben op het gebied van verantwoord beleggen en zo ja, hoe ze dit operationaliseren en uitvoeren in de praktijk. In het rapport "De Kracht van Pensioenfondsen" (Hummels, 2007a) laat hij zien dat ongeveer de helft van de Nederlandse pensioenfondsen een verantwoord beleggingsbeleid heeft opgesteld. Het rapport laat echter tevens zien dat de vertaling van beleid naar uitvoering, alsmede transparantie en verantwoording over het gevoerde beleid nog duidelijk voor verbetering vatbaar zijn. En let wel: dat zijn de fondsen die de enquête hebben ingevuld!

Maar waarom zou een pensioenfonds, afgezien van ethische motieven, eigenlijk verantwoord moeten beleggen? De meest filosofische beweegreden is dat pensioenfondsen en andere grote institutionele beleggers gezamenlijk een dusdanig groot deel van de economie bezitten via hun beleggingen dat ze in feite universele beleggers zijn? Universele beleggers hebben een zeer lange beleggingshorizon en zijn vanwege hun grootte genoodzaakt posities aan te houden in een 
groot aantal verschillende ondernemingen. Op die manier hebben deze beleggers als het ware een aandeel in de economie als geheel en niet louter in individuele ondernemingen. Strikt genomen betekent dit dat een universele belegger ondernemingen zou moeten stimuleren om zich dusdanig te gedragen dat ook positieve effecten optreden bij de rest van de ondernemingen in de economie. Een goed voorbeeld is opleiding en training van het personeel. Hoewel een goed opgeleid personeelsbestand bijdraagt aan de totale economie, zullen ondernemingen in veel gevallen niet genoeg investeren in hun personeel. Dat kan allerlei redenen hebben, bijvoorbeeld te veel aandacht voor korte termijn winstcijfers of de vrees dat goed opgeleide werknemers het bedrijf onmiddellijk verlaten na hun opleiding. Universele beleggers zijn er bij gebaat om ondernemingen aan te zetten tot optimale investeringen in hun medewerkers. De positieve externe effecten stralen uit op de economie als geheel en dus op alle ondernemingen die de universele belegger in zijn portefeuille heeft. Een ander motief om verantwoord te beleggen is dat pensioenfondsen de opdracht hebben gekregen om het vermogen van werknemers en werkgevers als een goed rentmeester te beheren. Dat houdt onder meer in dat van een pensioenfonds mag worden verwacht dat het zicht heeft op de financiële en maatschappelijke gevolgen van het gevoerde beleid en dat het zich vergewist van de mogelijke negatieve effecten voor de samenleving. Pensioenfondsen noemen desgevraagd ook dat de integratie van sociale en milieufactoren in het beleggingsbeleid goed aansluit bij het corporate governance beleid van het pensioenfonds ${ }^{8}$.

Nadat het stof van de documentaire van Zembla was neergedaald, hebben de drie Nederlandse pensioenkoepels 9 een Praktische Commissie ingesteld onder leiding van professor Hummels. Het rapport van de commissie, "De gearriveerde toekomst", is gepubliceerd en aangeboden aan Minister Donner in november 2007. Het is speciaal bedoeld voor pensioenfondsen die zich willen oriënteren op het vraagstuk verantwoord beleggen. Mede als gevolg hiervan zijn Nederlandse pensioenfondsen sindsdien druk bezig met het opstellen van een verantwoord beleggingsbeleid en in sommige gevallen met de start van de operationalisering en de implementatie van dat beleid. De meeste fondsen kiezen in de praktijk voor een of meer van de drie onderstaande verschijningsvormen van verantwoord beleggen:

a. Uitsluiting: beleggingen die een pensioenfonds (of andere institutionele belegger) expliciet wenst uit te sluiten, omdat de 
onderliggende ondernemingen of entiteiten niet beantwoorden aan de vastgelegde ESG-criteria,

b. Insluiting: de informatie van ESG-criteria wordt nadrukkelijk geïntegreerd in het reguliere beleggingsproces van een pensioenfonds. Dat kan betekenen dat bepaalde ondernemingen op grond hiervan worden geselecteerd, maar ook dat beleggingen in bepaalde ondernemingen worden vermeden omdat verwacht wordt dat ze vanwege lage scores op ESG-factoren slecht zullen presteren. Het expliciete doel van deze vorm van verantwoord beleggen is om een betere verhouding tussen rendement en risico voor de beleggingsportefeuille op de lange termijn te bewerkstelligen. verantwoord beleggen als kans dus.

c. Engagement: het gebruik van aandeelhoudersrechten waaronder het stemrecht en het recht om invloed uit te oefenen op de leiding van de onderneming. Strikt genomen is dit geen vorm van beleggen en mede daarom sluit ik het grotendeels uit in deze rede.

Pensioenfondsen zijn niet de enige beleggers die het thema verantwoord beleggen zo bewust oppakken. In de Nederlandse context kennen we bijvoorbeeld een aantal beleggingsfondsen die harde eisen stellen aan de ondernemingen in de beleggingsportefeuille. Het ASN aandelenfonds is daar een goed voorbeeld van. Op de website van ASN staat vermeld ${ }^{10}$ :

"Het fonds belegt wereldwijd in aandelen van beursgenoteerde bedrijven die voldoen aan onze sociale, maatschappelijke en milieucriteria. Behalve op maatschappelijke verantwoordelijkheid, letten we scherp op onder andere kwaliteit en winst. Het doel is tweeledig: bevordering van de duurzaamheid van de samenleving en vooruitzicht op hoog rendement, dit in combinatie met een verantwoord risico."

In het prospectus van de ASN beleggingsfondsen staat iets duidelijker dan in de beknopte financiële bijsluiter dat ASN een substantieel aantal ondernemingen uitsluit. Navraag bij het beleggingsfonds leert dat ASN zich richt op de Morgan Stanley Wereld Index (MSCI) die op dit moment 1950 ondernemingen bevat. ASN heeft tot op heden ruim 600 ondernemingen geëvalueerd. Van deze groep zijn slechts 108 ondernemingen toegelaten tot het aandelenuniversum van het ASN beleggingsfonds. Ruim 1800 ondernemingen worden dus 
vooralsnog niet toegelaten of zijn expliciet uitgesloten van opname in het universum. Toch belooft het beleggingsfonds een hoog rendement met een verantwoord risico. Kan het dat waarmaken?

Een ander concreet voorbeeld is het uitsluitingsbeleid van de charitatieve instelling KWF Kankerbestrijding. Dit fonds werd in een vervolguitzending van Zembla geconfronteerd met beleggingen in ondernemingen die tabak produceren. Hoewel het een belegging van slechts $0,21 \%$ van het vermogen betrof, corresponderend met 300.000 euro, nam KWF nog op de avond van de uitzending maatregelen. De directeur verwoordde het als volgt op de website van KWF:

"Hoe gering ook, beleggen in tabak is in strijd met het beleid van KWF Kankerbestrijding. Er is immers een directe relatie tussen roken en kanker. KWF Kankerbestrijding gaat hier dan ook direct een einde aan maken. En neemt maatregelen om te voorkomen dat dit opnieuw gebeurt."

ASN en KWF zetten dus beiden op hun eigen manier actief en bewust in op een uitsluitingsbeleid. Zeker in het geval van KWF is het verband met de identiteit van de charitatieve instelling zeer duidelijk.

Het Noorse staatspensioenfonds dat de gigantische olieopbrengsten van Noorwegen belegt om de pensioenvoorziening van Noorwegen op lange termijn veilig te stellen, kijkt weer anders tegen de zaak aan. Het fonds stelt duidelijk dat het niet wil beleggen in (dochters van) ondernemingen die wapens produceren waarvan het normale gebruik leidt tot onaanvaardbaar menselijk leed. Bovendien kiest het fonds voor uitsluiting van ondernemingen die een onacceptabel risico lopen dat ze bijdragen aan ernstige schendingen van mensenrechten, ernstige milieuproblemen, ernstige schendingen van individuen in tijden van oorlog, corruptie of andere ernstige vormen van het schenden van ethische normen ${ }^{11}$. Gegeven deze opsomming is het op zijn minst gezegd opmerkelijk dat het fonds op dit moment wereldwijd slechts 27 ondernemingen uitsluit. Een derde activiteit van het Noorse fonds is actief stemgedrag om lange termijn adequate financiële rendementen te bevorderen, mede geïnspireerd op de Global Compact van de Verenigde Naties en de OECD richtlijnen voor corporate governance en multinationals. 
Het merendeel van de uitsluitingen van het staatspensioenfonds geschiedt vanwege de productie van wapens. Een van de uitgesloten ondernemingen is Boeing, de bekende Amerikaanse vliegtuigproducent. Volgens de adviseurs van het Noorse fonds is Boeing actief betrokken bij de productie van kernwapens. Om die reden wordt het bedrijf uitgesloten. Maar het kan ook anders. Velen van ons zitten in een Boeing als ze op vakantie gaan evenals de piloten van KLM tijdens hun dagelijkse werk. Die piloten bouwen hun pensioen op via het pensioenfonds van KLM. Het ligt niet voor de hand dat KLM pensioenfonds Boeing uitsluit van haar beleggingsuniversum. Heeft dit smaakverschil financiële gevolgen?Zoals blijkt uit het rapport Hummels (2007a) heeft een minderheid van de Nederlandse pensioenfondsen een uitgewerkt en operationeel verantwoord beleggingsbeleid. De meeste pensioenfondsen hebben in mijn eigen waarneming geen of hooguit een beperkt uitsluitingsbeleid. Het pensioenfonds Zorg en Welzijn (PFZW, voorheen PGGM) sluit bijvoorbeeld omstreeks 30 ondernemingen uit. De voornaamste redenen voor uitsluiting zijn betrokkenheid van deze ondernemingen bij de productie van nucleaire wapens, clusterbommen en landmijnen. Enkele grote Nederlandse pensioenfondsen integreren ESG-criteria in toenemende mate in het reguliere beleggingsproces ${ }^{12}$. Zij zetten dus vooral in op een positieve bijdrage van verantwoord beleggen aan het rendement- en risicoprofiel. Hierbij dient wel aangetekend te worden dat het gros van deze beleggingen plaatsvindt in het domein van aandelenbeleggingen en zogenaamde doelinvesteringen. Van substantiële integratie van ESGfactoren in het portefeuillemanagement van vastrentende waarden en vastgoed is nauwelijks sprake. Het merendeel van de overige Nederlandse pensioenfondsen kijkt de kat uit de boom en richt zich vooral op de formulering van het uitsluitingsbeleid dat meer aandacht krijgt in de pers en dus meer reputatierisico voor het pensioenbestuur impliceert.

\section{De praktijk is weerbarstig}

Wat verklaart de terughoudendheid van de meeste Nederlandse pensioenfondsen op het gebied van verantwoord beleggen? Mogelijk zijn er juridische motieven. Rene Maatman, mijn voormalige collega bij ABP Vermogensbeheer en tevens hoogleraar Vermogensbeheer aan de juridische faculteit van de Radboud Universiteit Nijmegen, haalt in deze context graag artikel 135 lid 1 van de Pensioenwet aan. Hierin wordt 
bepaald dat pensioenfondsen een beleggingsbeleid dienen te voeren dat in overeenstemming is met de zogenaamde prudent-person-rege ${ }^{13}$. Deze regel is ontleend aan de Europese Pensioenrichtlijn en behelst kort samengevat dat pensioenfondsen in Nederland de verantwoordelijkheid dragen om het vermogen te beheren in het financiële belang van de begunstigden. Daarbij dienen alle begunstigden van het fonds, te weten actieve deelnemers, slapers en natuurlijk pensioengerechtigden, gelijk behandeld te worden. Het vermogensbeheer dient deskundig te worden uitgevoerd op een wijze die de veiligheid, de kwaliteit, de liquiditeit en het rendement van de portefeuille als geheel waarborgt. Dit betekent dat het risico- en rendementsprofiel van de totale portefeuille steeds afgestemd moet zijn op de structuur van de verplichtingen van het fonds en dat de beleggingen voldoende gespreid moeten zijn. Maatman concludeert dat pensioenfondsen in de Europese context verplicht zijn om aannemelijk te maken dat ze in alle gevallen voorrang hebben gegeven aan de belangen van hun begunstigden. Hij stelt:

"Een pensioenfonds heeft onder het Nederlandse recht de vrijheid om bepaalde beleggingen te verrichten of na te laten (screening), mits dit niet ten koste gaat van de financiële belangen van de begunstigden."

De volgende vraag rijst nu: welke consequenties heeft deze interpretatie van de wetgeving voor de wijze waarop Nederlandse pensioenfondsen het thema verantwoord beleggen in de praktijk integreren in hun beleggingsbeleid? De drie eerdergenoemde vormen van verantwoord beleggen zouden immers in de praktijk wel degelijk financiële consequenties kunnen hebben. Een zeer restrictief uitsluitingsbeleid heeft wellicht gevolgen voor de mogelijkheid tot risicospreiding van de portefeuille als geheel.

Laat ik een eenvoudig voorbeeld geven. Stel dat een pensioenfonds besluit om haar aandelenbeleggingen uit te besteden aan het eerdergenoemde ASN aandelenfonds. Dit beleggingsfonds heeft maximaal een honderdtal maatschappelijkverantwoordeondernemingen in portefeuille.Duizenden beursgenoteerde ondernemingen wereldwijd worden dus expliciet uitgesloten. Met dit geringe aantal ondernemingen in de portefeuille is de kans groot dat de aandelenportefeuille niet goed vertegenwoordigd is alle relevante landen en sectoren van de wereldeconomie met mogelijk negatieve gevolgen voor het rendement en risico van de portefeuille. Hoe wordt nu bepaald of deze vorm van verantwoord beleggen voor een 
pensioenfonds juridisch geoorloofd is? Als een deelnemer dit fonds voor de rechter sleept, hoe en met welk instrumentarium moet de rechter dan bepalen of er sprake is van een portefeuille die niet voldoet aan de eisen gesteld in de prudent-person-regel? Dat is precies het gebied waar de objectieve bijdrage van financiële economen zeer gewenst is. Zij kunnen licht werpen op vragen als: leidt uitsluiting inderdaad tot inefficiënte portefeuilles in termen van risico en rendement? Geldt dat voor elke vorm van uitsluiting? Kunnen financieel en maatschappelijk rendement inderdaad met elkaar samengaan? Wat is de invloed van engagement door beleggers op het gedrag van ondernemingen en uiteindelijk de rendementen en waarderingen van deze ondernemingen op de beurs?

Voor juristen, geachte rector, zijn ook voldoende interessante vragen over. Ik noem graag enkele zaken die mij als leek op juridisch terrein al een tijdje bezighouden: is uitsluiting juridisch geoorloofd als pensioenfondsen deze beleidskeuze ex ante motiveren met de uitleg dat de uitgesloten ondernemingen op lange termijn slechter zullen presteren dan de rest van de beurs? Het uitsluitingsbeleid kan dan net als bij het ASN aandelenfonds geïnterpreteerd worden als een actieve beleggingsbeslissing met een lange termijn horizon. De actieve beleggingsstrategie is doorspekt met onzekerheden zoals iedere andere actieve strategie, maar heeft expliciet de intentie om waarde toe te voegen. Maar hoe moet een rechter bepalen of deze intentie juridisch geoorloofd is in het licht van de prudent-person-regel? Ik ben ook zeer geïnteresseerd in jurisprudentie over het falen van regulier actief beleggingsbeleid. Pensioenfondsen kiezen niet zelden voor actieve beleggingsmandaten, d.w.z. mandaten waarin een portefeuillemanager of een externe vermogensbeheerder tracht de beursindex te verslaan met een beperkt aantal aandelen. Kan een deelnemer een pensioenfonds bijvoorbeeld ter verantwoording roepen indien zou blijken dat het actieve beleggingsbeleid van het fonds heeft geleid tot slechtere rendementen dan de beursindex? Ik hoop het zeer voor de advocatuur, want er zou zeer waarschijnlijk behoorlijk wat werk op ze afkomen. Dit voorbeeld staat niet zo ver af van de discussie over uitsluiting, want in beide gevallen gaat het om uitsluiting van een groot aantal ondernemingen op enig moment ${ }^{14}$.

Een tweede reden waarom verantwoord beleggen in de praktijk nog geen gemeengoed is, heeft te maken met een aantal notoire 
belangenconflicten in de financiële sector. Ik geef twee voorbeelden. Kunt $u$ zich voorstellen dat een beursgenoteerde levensverzekeraar als aandeelhouder een beursgenoteerde onderneming in de algemene aandeelhoudersvergadering aanspreekt op een falend milieubeleid, als diezelfde onderneming een vaste klant is bij dieverzekeringsmaatschappij in de schadepoot? Weer een ander voorbeeld is de salaris- en bonusstructuur van portefeuillemanagers bij financiële instellingen. In de meeste gevallen zijn zij niet al te bekend met informatie die kan worden gedestilleerd uit ESG-factoren. En onbekend maakt onbemind, zeker als uitsluiting in hun perceptie leidt tot minder keuzevrijheid en impliciet dus minder kans op een substantiële bonus. Deze bonus is in principe een soort calloptie waarvan de waarde onmiddellijk daalt indien de keuzevrijheid van de portefeuillemanager door uitsluiting van een groep aandelen wordt beperkt. Waarschijnlijk verklaart dit laatste fenomeen waarom menig portefeuillemanager zodra de term duurzaam of verantwoord beleggen valt op een bijna Pavloviaanse wijze het tegenargument opdreunt dat restricties in het universum leiden tot minder efficiënte portefeuilles en dus lagere voor risico gecorrigeerde rendementen. Steeds als ik deze reactie krijg van vermogensbeheerders tijdens talloze presentaties over dit thema in binnen- en buitenland, schiet de bekende slogan uit reclamespotjes van beleggingsfondsen door mijn hoofd:

"Resultaten uit het verleden zijn geen garantie voor de toekomst".

Op zichzelf is het al verwonderlijk om die laatste toevoeging aan een reclameboodschap te begrijpen gezien de snelheid waarmee ze wordt uitgesproken. Er wordt iets heel moois beloofd, maar tegelijkertijd wordt gesteld dat er een reële kans is dat de belofte niet waargemaakt zal worden. Nogal wat pensioenfondsen beleggen in beleggingsfondsen. Hoe verhoudt zich dat tot de prudent-person-regel?

De discussie met tegenstanders van verantwoord beleggen verloopt dikwijls volgens een vast patroon. Ik noem het graag de three lines of defense to responsible investing. Als een sceptisch portefeuillemanager of analist wordt gevraagd of hij ESG-factoren integreert in zijn beleggingsbeleid, stelt hij dikwijls dat het reeds geruime tijd gebeurt. Aandacht voor de kwaliteit van het bestuur van de onderneming wordt dan vaak als voorbeeld aangehaald. Als deze sceptici vervolgens geconfronteerd worden met de beschikbare ESG-informatie in de volle 
breedte, is de reactie al snel dat deze informatie al weerspiegeld wordt in aandelenkoersen, of dat de informatie simpelweg niet relevant is voor de prijsvorming op de beurs. Deze drie verdedigingslinies worden nauwelijks losgelaten op de traditionele wijze van actief beleggen waar eenzelfde kritische houding mijns inziens op zijn minst net zo gerechtvaardigd is. De weerbarstige houding van zowel beleidsmakers en uitvoerders van het beleggingsproces heeft ertoe geleid dat een aanzienlijk aantal institutionele beleggers het thema verantwoord beleggen nog in het vriesvak hebben liggen.

Een derde reden voor de sceptische houding van veel beleggingsprofessionals is de kwaliteit en beschikbaarheid van ESGinformatie. Sinds de jaren tachtig zijn verschillende onafhankelijke instituten begonnen met het scoren van ondernemingen op ESGfactoren. De kwaliteit en diepgang van de databases zijn doorgaans niet van dien aard dat fundamenteel en longitudinaal onderzoek zonder meer mogelijk is, zie bijvoorbeeld Chatterji en Levine (2006). Data worden ook niet zelden regionaal verzameld. Instituten die gevestigd zijn in de Verenigde Staten hanteren bijvoorbeeld andere criteria en andere wegingen dan Europese instituten. Het gevolg is dat een belegger met een globale aandelenportefeuille moeilijk informatie kan verzamelen die uniform kan worden ingezet in het beleggingsproces. Bovendien stellen Chatterji en Levine (2006) de betrouwbaarheid en validiteit van de data ter discussie. Conclusies zijn dus moeilijk te trekken en dat is natuurlijk voer voor onvoorwaardelijke tegenstanders van verantwoord beleggen. ECCE heeft zich daarom ten doel gesteld om de kwaliteit van de scores van deze instituten te onderzoeken. Veel instituten werken hier al aan mee door de scores ter beschikking te stellen aan ECCE onderzoekers voor wetenschappelijk onderzoek.

De zaak ligt bovendien nogal genuanceerd. De twee basisvormen van verantwoord beleggen, uitsluiting en insluiting, hebben fundamenteel verschillende beweegredenen. In het geval van uitsluiting is vrijwel altijd sprake van niet-financiële motieven. Op basis van ethische keuzes, emotie of smaak bepalen beleggers of een bepaalde onderneming dient te worden uitgesloten van het aandelenuniversum. Financiële motieven spelen hierbij doorgaans geen rol. Bij insluiting daarentegen wordt de ESG-informatie geïnterpreteerd als relevante extrafinanciële informatie. De term extrafinanciële informatie kan worden gedefinieerd als informatie die niet expliciet financieel van aard is, maar die wel degelijk financiële consequenties kan hebben voor de prijsvorming van 
de onderneming op de beurs. Denk bijvoorbeeld aan de kwaliteit van het personeelsbeleid of het milieubeleid van een onderneming. De vraag of het verantwoorde beleggingsbeleid van een pensioenfonds voldoende rekening houdt met diversificatie van de portefeuille als geheel kan dus niet eenvoudig en eenduidig beantwoord worden. Eerst moeten we weten hoe het fonds haar beleid uitvoert.

Gelukkig hebben financieel-economischewetenschappers het onderwerp verantwoord beleggen niet helemaal genegeerd. De wetenschappelijke literatuur op het gebied van verantwoord beleggen is intussen de luiers ontgroeid, mede onder impuls van medewerkers verbonden aan ECCE en een toenemende groep internationale wetenschappers uit het vakgebied Financiering. Ik durf best te stellen dat de volwassenheid lonkt, maar het laatste woord over de bovenstaande vragen is zeker nog niet geschreven. In de volgende twee paragrafen zal ik aangeven hoe de financieel-economische literatuur dit thema tot op heden theoretisch en empirisch heeft opgepakt.

\section{Niet-financiële motieven: ethiek, emotie en smaak}

De moderne portefeuilletheorie veronderstelt dat beleggers een risicopremieeisenvooreen belegginginde aandelenvaneen onderneming. Aangezien rationele beleggers breed gespreide portefeuilles aanhouden met posities in een groot aantal ondernemingen, is deze premie slechts een vergoeding voor dat deel van het risico dat niet door spreiding kan worden voorkomen. De theorie is voorts gebaseerd op een aantal additionele veronderstellingen: bijvoorbeeld homogene verwachtingen van beleggers, perfecte kapitaalmarkten, de afwezigheid van transactiekosten en belastingen, en de afwezigheid van restricties om te handelen.

Een relevante vraag in de context van verantwoord beleggen is of de aanwezigheid van een groep beleggers met bepaalde afwijkende sociale normen en voorkeuren leidt tot een gesegmenteerde kapitaalmarkt. Die segmentatie is strikt genomen een schending van de veronderstelling van perfecte kapitaalmarkten en de homogeniteit van verwachtingen van beleggers. Er zijn immers aandelen waarin een bepaalde groep normgedreven beleggers niet wil beleggen en waarin niet normgedreven beleggers in principe wel willen beleggen. Eerder werk van Nobelprijswinnaar Robert Merton (1987) is gerelateerd 
aan deze vraagstelling. Hij onderzocht de effecten op zogenaamde "neglected stocks". Vrij vertaald zijn dat gediscrimineerde aandelen. In een wat algemenere context zijn dit aandelen waarin weinig gehandeld wordt omdat de onderliggende ondernemingen relatief klein en onbeduidend zijn, of weinig verhandeld worden op de beurs, of omdat een bepaalde groep beleggers ze niet wil bezitten om andere redenen. Uit het werk van Merton kan worden afgeleid dat gediscrimineerde aandelen goed koper zullen zijn dan vergelijkbare aandelen met dezelfde financieel-economische kengetallen (dus ondergewaardeerd). De segmentatie zou kunnen leiden tot een situatie waarin ondernemingen die geboycot worden door een significante groep normgedreven beleggers hogere kapitaalkosten hebben dan verwacht mag worden volgens de financiële theorie. De relatief kleine groep "sin" beleggers eist namelijk een compensatie voor het opnemen van geboycotte ondernemingen in hun aandelenportefeuille. Zij kunnen hun risico minder spreiden dan normgedreven beleggers, omdat niet iedereen deze boycotaandelen wil bezitten. Als gevolg hiervan hebben deze beleggers naar verhouding veel van deze aandelen in portefeuille. Dus alleen als ze extra gecompenseerd worden in termen van rendement, zullen ze deze aandelen willen aanhouden. Daarnaast lopen bezitters van "sin stocks" het risico dat de geboycotte ondernemingen voor de rechter gedaagd worden voor bepaalde producten die ze verkopen. Denk bijvoorbeeld aan tabaksproducerende ondernemingen die jarenlang een groot aantal schadeclaims in het vooruitzicht hadden. Het model van Merton impliceert dat het risico op schadeclaims in het geval van gesegmenteerde markten wordt gecompenseerd, terwijl dat uitdrukkelijk niet het geval is in modellen die direct afgeleid zijn van de financiële theorie.

Is de groep Amerikaanse beleggers die ondernemingen boycotten of discrimineren groot genoeg om een significant effect te hebben op de kapitaalkosten van ondernemingen'15? Recent hebben twee wetenschappers (Hong en Kacperczyk, 2007) empirisch onderzocht welke invloed normgedreven beleggers hebben op de eerdergenoemde sin stocks in de Verenigde Staten. De auteurs definiëren sin stocks als ondernemingen in sectoren die bekend staan als het Triumviraat van de Zonde: alcohol, tabak en gokken. Zij laten zien dat beleggers die breed in de publieke belangstelling staan in verhouding weinig beleggen in sin stocks. Denk hierbij aan pensioenfondsen, universiteiten, religieuze instellingen en verzekeraars. Beleggingsfondsen, hedge funds en 
particuliere beleggers blijken echter naar verhouding veel in dit type ondernemingen te beleggen. De auteurs noemen beleggingsfondsen de natuurlijke arbitrageurs om de onderwaardering van sin stocks op te pikken ${ }^{16}$. Hoewel ik dit gezien de beleggingsresultaten van beleggingsfondsen een te groot compliment vind, wordt het beeld bevestigd dat sin stocks in de Verenigde Staten door een substantiële groep beleggers geboycot worden. Ze worden overigens niet alleen door beleggers genegeerd, maar ook systematisch door analisten van banken. Dit versterkt in feite het discriminerende effect, want beleggers krijgen dus naar verhouding weinig informatie over deze aandelen met als gevolg meer onzekerheid. Angel en Rivoli (1997) kwantificeren de verhoging van de kapitaalkosten van gediscrimineerde ondernemingen met behulp van het theoretische model van Merton (1987). Slechts wanneer een onderneming door meer dan de helft van de beleggers wordt geboycot, stijgen de kapitaalkosten van de onderneming significant.

Laat ik een voorbeeld geven om de effecten van discriminatie van aandelen duidelijker te illustreren. Het produceren van tabak wordt in de Verenigde Staten in sommige kringen pas sinds het midden van de jaren zestig beschouwd als een activiteit tegen de sociale norm. Het rapport van de "Surgeon General's Advisory Committee on Smoking and Health" concludeerde in 1964 ondubbelzinnig dat roken kan leiden tot longkanker. In 1965 leidde dat al snel tot waarschuwingen op pakjes sigaretten en in 1971 tot het verbod om tabaksreclame te maken op radio en televisie. Beleggen in de tabaksindustrie was vanaf dat moment in de ogen van bepaalde beleggers een zonde. De tabaksindustrie is overigens een interessante case, want in de 16e eeuw werd tabak nog gezien als een medicijn in navolging van de indianen in Amerika. We kunnen dus een periode onderscheiden waarin beleggen in tabak niet als tegen de sociale norm werd beschouwd $(1555-1964)$ en een periode waarin het tegendeel het geval is (1964 - heden). Uit het empirisch onderzoek van Hong en Kacperczyk (2007) blijkt dat tabaksaandelen op de Amerikaanse beurs hogere voor risicogecorrigeerde rendementen behaalden na 1964, terwijl ze presteerden conform verwachtingen in de periode daarvoor ${ }^{17}$. Beleggers in tabaksaandelen ontvangen dus op lange termijn een risicopremie die mogelijk samenhangt met de normgedreven onderwaardering en het verhoogde liquiditeitsrisico ${ }^{18}$.

De onderzoekers Geczy, Stambaugh en Levin (2005) analyseren het effect van uitsluiting op de efficiëntie van aandelenportefeuilles op een 
andere wijze. Zij kwantificeren het mogelijke nutverlies voor beleggers in duurzame beleggingsfondsen als gevolg van de impliciete restrictie van het beleggingsuniversum door uitsluiting van gediscrimineerde aandelen. Zij concluderen dat duurzame beleggers met een rotsvast geloof in efficiënte markten naar verwachting weinig te duchten hebben van de inherente restricties van het beleggingsuniversum. Voor die groep beleggers geldt dat de rendement- en risicokenmerken van uitgesloten ondernemingen ogenschijnlijk redelijk eenvoudig nagebootst kunnen worden door andere ondernemingen in het beschikbare universum van duurzame beleggingsfondsen. Het verlies aan diversificatie is marginaal.

Graag illustreer ik deze gedachtegang aan de hand van een anekdote. Enkele jaren geleden werd ik geheel onverwacht gebeld door een journalist van The International Herald Tribune. Hij vroeg mij of de beslissingvan het Noorsestaatspensioenfonds om zeven ondernemingen uit te sluiten vanwege de productie van clusterbommen negatieve gevolgen zou hebben voor de efficiëntie van de beleggingsportefeuille van de Noren. Ik zat midden in de trein en wilde het gesprek kort houden en vroeg: "Wat denkt u zelf?". "Lijkt mij zeer onwaarschijnlijk", was zijn antwoord en het gesprek was vrijwel meteen voorbij. Het spreekt natuurlijk voor zich dat de uitsluiting van slechts zeven ondernemingen uit een beschikbaar universum van duizenden ondernemingen geen materiële impact zal hebben op het rendement en risico van de portefeuille als geheel.

In het vervolg van de studie van Geczy et al. (2007) wordt aangegeven dat de beperking tot een universum van duurzame beleggingsfondsen mogelijk leidt tot een significant disnut voor beleggers als ze het geloof hebben dat de multi-factor modellen van Fama en French (1993) de prijsvorming van aandelen op de beurs beter weergeven ${ }^{19}$. Te drastische en systematische uitsluiting van ondernemingen uit bepaalde sectoren van de economie als gevolg van de beperking van het universum tot duurzame beleggingsfondsen, leidt blijkbaar wel tot moeilijkheden bij de vorming van efficiënte portefeuilles. De situatie is weer anders als beleggers inschatten dat portefeuillemanagers van beleggingsfondsen daadwerkelijk in staat zijn om de marktindex te verslaan. In die context voelen beleggers direct de inperking van het universum van beleggingsfondsen. Ze kunnen de best presterende fondsen niet selecteren aangezien het veel grotere universum van niet- 
duurzame beleggingsfondsen wordt uitgesloten. Hetzelfde geldt voor een portefeuillemanager van een duurzaam beleggingsfonds. Stel dat hij gespecialiseerd is in de actieve selectie van defensieaandelen. Op een dag verandert het normale beleggingsfonds echter in een duurzaam fonds en mag de portefeuillemanager plotseling niet meer beleggen in de defensiesector. In die context kan hij zijn volledige potentieel niet meer laten zien.

Deze bijdrage aan het debat illustreert dat de strategische visie van een pensioenfonds op actief beleggen wezenlijk is bij het vaststellen van de wenselijkheid van een uitsluitingsbeleid. Een pensioenfonds met een overwegend passief beleid hoeft als gevolg van een beperkt uitsluitingsbeleid nauwelijks negatieve effecten te verwachten op de efficiëntie van de beleggingsportefeuille. Heeft het fonds echter een groot vertrouwen in de toegevoegde waarde van zijn interne en externe vermogensbeheerders, dan kan een te strikt uitsluitingsbeleid mogelijk contraproductief werken. Deze constatering toont overigens aan dat het door PGGM voorgestelde verantwoord beleggingsbeleid heel goed past bij de keuze om actief vermogensbeheer in de categorie aandelen te mijden. Door te kiezen voor passief management heeft PGGM als het ware meer speelruimte om in te zetten op verantwoord beleggen.

Een tweede groep empirische studies ten aanzien van duurzame beleggingsfondsen documenteert dat deze fondsen gelijkwaardige rendementen kunnen behalen en hetzelfde niveau van portefeuillespreiding. Een voorbeeld hiervan is het onderzoek van Bauer, Koedijk en Otten (2005). In dat vaak door voor- en tegenstanders geciteerde onderzoek laten zij zien dat duurzame beleggingsfondsen niet beter of slechter presteren dan conventionele beleggingsfondsen. Een saillant detail is echter de constatering dat zowel duurzame als conventionele beleggingsfondsen substantieel slechter presteren dan de beurs als geheel. Aanpalend onderzoek van Bello (2005) toont aan dat duurzame beleggingsfondsen en conventionele fondsen min of meer hetzelfde diversificatieniveau hebben en gelijkwaardige lange termijn rendementen. Een onderzoek van Schroeder (2007) inventariseert de prestaties van duurzame indices (bijvoorbeeld de FTSE4Good of de Dow Jones Sustainability Index). In de meeste gevallen presteren deze indices - die een actieve selectie maken uit het beschikbare aandelenuniversum - in rendementstermen niet minder dan reguliere indices (bijvoorbeeld de Morgan Stanley Capital International index). 
Bij sommige indices is echter wel sprake van een enigszins verhoogd risico. Enige terughoudendheid bij de interpretatie van de bovenstaande onderzoeken naar verantwoorde beleggingsfondsen en indices is wenselijk. Niet elk fonds of index hanteert daadwerkelijk een stringent uitsluitingsbeleid. Al te ferme conclusies over de invloed van een uitsluitingsbeleid op rendementen en risico's kunnen dus op grond van deze onderzoeken moeilijk getrokken worden. Feit is wel dat de meest gangbare vormen van uitsluiting niet per se hoeven te leiden tot inefficiënte aandelenportefeuilles.

De discussie over de wenselijkheid van uitsluiting zou ik graag willen afsluiten met enkele relativerende opmerkingen over actief beleggingsbeleid. Portefeuillemanagers van reguliere actieve aandelenportefeuilles hanteren in wezen ook een vorm van uitsluitingsbeleid. Het verschil is echter dat zij op basis van financiële kengetallen, fundamentele analyse of kwantitatieve analyse een groot deel van de ondernemingen in het universum expliciet niet in hun portefeuille opnemen. De ratio is duidelijk: zij schatten in dat deze ondernemingen relatief minder zullen renderen dan de beursindex (de benchmark) die zij moeten verslaan om hun bonus veilig te stellen ${ }^{20}$. Natuurlijk kunnen die ondernemingen op basis van financiële overwegingen op een later tijdstip desgewenst weer toegevoegd worden, maar het is een feit dat iedere actieve portefeuille op enig moment een significante deelverzameling van het universum bewust uitsluit. Ik doop deze vorm van uitsluiten vandaag tot een dynamisch uitsluitingsbeleid. De mate waarin portefeuillemanagers van actieve aandelenportefeuilles in staat zijn om systematisch de beursindex te verslaan door dynamische uitsluiting bepaalt wat mij betreft of zij prudent gehandeld hebben, oftewel in het financieel belang van de begunstigden van het pensioenfonds. Deze vraag is in de beleggingsliteratuur al decennialang uitvoerig bestudeerd met databases van zeer hoge kwaliteit. Bekende voorbeelden zijn de studies van Malkiel (1995) en Gruber (1996) die onomstotelijk aantonen dat actieve beleggingsfondsen in de regel niet in staat zijn om de beurs als geheel te verslaan. Sterker nog: na kosten resteert voor $u$ als belegger in actieve beleggingsfondsen gemiddeld een significant lager rendement dan de beursindex van ruim 1,0\% per jaar. Nu vraag ik $u$ hier in de zaal: welk uitsluitingsbeleid heeft grotere gevolgen voor een particuliere belegger of deelnemer van een pensioenfonds? Een beperkt uitsluitingsbeleid toegepast op een overigens passieve 
beleggingsstrategie zoals bij PGGM of een slecht scorend dynamisch uitsluitingsbeleid dat je aantreft bij de meerderheid van de actieve beleggingsfondsen? Welk van beide beleggingsvormen past beter bij de prudent-person-regel? Een uitdaging voor juristen wat mij betreft.

De lessen die we kunnen leren uit de bovenstaande onderzoeken is dat elk uitsluitingsbeleid vooraf moet worden getoetst op de invloed die het heeft op de efficiëntie van de portefeuille. Het op voorhand uitsluiten van een groot aantal ondernemingen in een universum vanwege het feit dat deze ondernemingen deel uitmaken van een bepaalde bedrijfstak of land kan leiden tot een drastische reductie van het aantal ondernemingen in het beleggingsuniversum. Minder keuze kan de efficiëntie van de portefeuille in gevaar brengen, zie bijvoorbeeld de recente studie van Galema, Plantinga en Scholtens (2008). Aan de andere kant tonen Milevsky, Aziz, Goss, Thomson en Wheeler (2004) aan dat een beperkt uitsluitingsbeleid, zoals het uitsluiten van een klein aantal ondernemingen uit een aandelenindex, geen negatieve gevolgen hoeft te hebben als er voldoende rekening wordt gehouden met de risicofactoren bij het construeren van de portefeuille. Sinds de opkomst van de moderne risicomodellen en -software is deze taak steeds eenvoudiger. Het spreekt vanzelf dat deze opgave moeilijker wordt naarmate meer ondernemingen worden uitgesloten. In de praktijk sluiten Nederlandse pensioenfondsen echter zelden of nooit hele sectoren van de economie uit van hun beleggingen. Het bewust beëindigen of opschorten van beleggingen in individuele ondernemingen komt wel voor, maar heeft veel minder ingrijpende gevolgen.

\section{Extrafinanciële motieven: verantwoord beleggen als kans!}

De integratie van extrafinanciële informatie in het reguliere beleggingsproces staat minder in de publieke belangstelling dan uitsluiting. De pers besteedt relatief veel aandacht aan uitsluiting in het beleggingsbeleid, maar in de media wordt zelden of nooit aandacht geschonken aan de toegevoegde waarde van de integratie van extrafinanciële informatie voor beleggers. Dat is opmerkelijk, want deze verschijningsvorm van verantwoord beleggen heeft wat mij betreft meer potentie om bij te dragen aan duurzaam beter werkende financiële markten. De integratie van extrafinanciële informatie is voor veel spelers op financiële markten een minder gevoelige kwestie dan uitsluiting. Er is immers geen sprake van een expliciete beperking van 
het universum, maar van de optie om de informatie mee te nemen in het beslissingsproces. Voorstanders pakken dit op en breiden hun informatieset uit en tegenstanders hebben de keuze om dit bewust niet te doen. Tot op heden integreren relatief weinig portefeuillemanagers informatie over ESG-factoren expliciet in hun beleggingsproces. Vaak wordt gekozen voor een thematische benadering voor een deel van de aandelenportefeuille of het stemmen op aandeelhoudersvergaderingen. Een belangrijke verklaring hiervoor is dat er in de wetenschappelijke literatuur geen consensus is over de toegevoegde waarde van het integreren van extrafinanciële informatie in het beleggingsproces.

Kunnen maatschappelijk rendement en financieel rendement inderdaad samengaan? Zijn beleggingen in ondernemingen die goed scoren op ESG-factoren minder risicovol? Tegenstanders van maatschappelijk verantwoord ondernemen wijzen op de onduidelijke focus van een onderneming indien deze zich zowel richt op winst maken als op andere maatschappelijke doelen, zie bijvoorbeeld Friedman (1970) en Henderson (2002). Beleggers in die ondernemingen zullen in hun ogen geconfronteerd worden met onverwacht lagere winsten vanwege directe en indirecte kosten die gepaard gaan met de aandacht voor andere dan primaire bedrijfsdoeleinden. Zij wapenen zich hiertegen door meer rendement te eisen. Voorstanders wijzen daarentegen op reputatie- en concurrentievoordelen voor ondernemingen die hoog scoren op het thema maatschappelijke verantwoordelijkheid, zie o.a. Porter en van der Linde (1995a en 1995b). Zij verwachten dat dergelijke ondernemingen op lange termijn meer innovatiekracht zullen bezitten en betere relaties met overige belanghebbenden als werknemers, verschaffers van vreemd vermogen en consumenten kunnen onderhouden. Het gevolg hiervan is dat vermogensverschaffers naar verwachting juist minder risicopremie eisen. Dat resulteert in lagere financieringskosten voor de onderneming. Beleggers profiteren hier onmiddellijk van als deze informatie nog niet geheel in de beurskoersen is verwerkt. Deze voornamelijk theoretische beschouwingen uit de managementliteratuur gingen helaas niet vergezeld van een rijk aanbod van empirisch onderzoek, hetgeen een jarenlange patstelling tussen de beide kampen tot gevolg heeft gehad. Onderzoek naar verantwoord beleggen bleef in de financieeleconomische literatuur nadrukkelijk een niche.

Naar mijn mening is het verschil tussen voor- en tegenstanders minder groot dan velen van hen inschatten. Deze stelling zou ik willen 
onderbouwen met een citaat over het belang van goed en gemotiveerd personeel voor moderne ondernemingen uit een studie van Zingales (2000):

"Employees are not merely automata in charge of operating valuable assets but valuable assets themselves, operating with commodity-like physical assets. The changing nature of the firm forces us to reexamine much of what we take for granted in corporate finance."

Zingales wijst op het toenemende belang van de productiefactor human capital of menselijk kapitaal voor moderne ondernemingen. In het begin van de jaren negentig van de vorige eeuw was een onderneming die voor haar productiviteit puur afhankelijk was van de kwaliteit van haar personeel een uitzondering. De opkomst van de technologiesector en aanverwante bedrijfstakken illustreert dat alleen die ondernemingen kunnen overleven die voortdurend in staat zijn om gekwalificeerde werknemers in vaak krappe arbeidsmarkten aan te trekken en te behouden. Michael Jensen (2001), grondlegger van de principaalagent theorie, niet bepaald bekend als aanhanger van maatschappelijk verantwoord ondernemen, schrijft zelfs:

"Creating value takes more than the acceptance of value maximization as the organizational objective. As a statement of corporate purpose or vision, value maximization is not likely to tap into the energy and enthusiasm of employees and managers to create value..... A firm cannot maximize value if it ignores the interest of its stakeholders."

Porter en van der Linde (1995a) verwoorden hetzelfde standpunt iets algemener:

"Properly designed environmental standards can trigger innovations that lower the total cost of a product or improve its value. Such innovations allow companies to use a range of inputs more productively - from raw materials to energy to labor - thus offsetting the cost of improving environmental impact and ending the stalemate. Ultimately, this resource productivity makes companies more competitive, not less."

Een voorbeeld van deze visie is het milieubeleid van ondernemingen. Stel dat een chemiereus substantieel investeert in research en ontwikkeling om de emissie van schadelijke stoffen in zijn productieproces tot 
een minimum te beperken. Deze onderneming zal wellicht eerder dan soortgelijke ondernemingen in staat zijn om zich aan te passen aan onverwacht strengere regelgeving en daardoor mogelijk concurrentievoordelen genieten. Eventueel kan de onderneming het productieproces laten patenteren en verkopen aan andere ondernemingen die gehouden zijn aan dezelfde milieuwetgeving. De investering betaalt zich in een dergelijke scenario dubbel en dwars terug. Porter en Kramer (2006) benadrukken dat intrinsieke aandacht voor maatschappelijk verantwoord ondernemen een belangrijke bijdrage kan leveren aan de concurrentiekracht en de lange termijnstrategie van ondernemingen. In hun visie zijn maatschappelijk en financieel rendement onlosmakelijk met elkaar verbonden en kunnen ze elkaar zelfs versterken. Ondernemingen kunnen niet floreren in een corrupte, armoedige en onderdrukte samenleving. Tegelijkertijd kan een goed werkende maatschappij niet zonder succesvolle ondernemingen met winstoogmerk.

Maar wat betekenen de bovenstaande observaties voor institutionele beleggers die het thema verantwoord beleggen in de praktijk willen implementeren? Hoe integreert een goedwillende portefeuillemanager deze visie op maatschappelijk verantwoord ondernemen in zijn beleggingsproces? Laat ik beginnen met een oude beleggerwijsheid:een goede onderneming is nog geen goede belegging. Het is goed mogelijk dat de relevante extrafinanciële informatie al in de beurskoersen is verwerkt. Dat betekent dat beleggers die zich voornemen om ESGinformatie voortaan te integreren in het beleggingsproces in feite achter het net vissen. Maar is die informatie inderdaad al verwerkt in beurskoersen op financiële markten? Een manier om deze vraag te beantwoorden is om een blik te werpen op de resultaten van enkele empirisch onderzoeken uit de drie domeinen van extrafinanciële informatie ( $E, S$ en $G$ ). Ik geef enkele voorbeelden, maar streef in de context van deze oratie geen volledigheid na. Voor een gedetailleerd overzicht van de empirische literatuur verwijs ik naar goede overzichten van Margolis en Walsh (2001), Orlitzky, Schmidt en Rynes (2003), Hummels en Bauer (2006), Derwall (2007) en Mercer Investment Consultants (2007b).

Empirisch onderzoek naar de relatie van milieubeleid (E) en sociaal beleid (S) met de financiële prestaties van ondernemingen heeft een betrekkelijk korte historie. De financieel-economische literatuur heeft 
het thema jarenlang min of meer genegeerd, maar de toegenomen aandacht voor het onderwerp in het publieke domein heeft ertoe geleid dat in het laatste decennium mondjesmaat onderzoeken op het snijvlak van maatschappelijk verantwoord ondernemen en beleggen werden opgestart. Voorbeelden op het gebied van milieumanagement (E) zijn twee recente studies waarin ECCE heeft onderzocht of de ecoefficiëntie van ondernemingen samenhangt met de financiële prestaties van ondernemingen ${ }^{21}$. Eco-efficiëntie kan worden omschreven als de mate waarin de onderneming competitieve producten en diensten kan leveren zonder daarbij het ecologische systeem aan te tasten ${ }^{22}$. Beide studies verbinden de inzichten uit de milieumanagementliteratuur met de performance- en risicometing uit de moderne financiering-en beleggingsliteratuur. Uit de onderzoeken blijkt dat portefeuilles van ondernemingen die hoog scoren op het gebied van eco-efficiëntie beter presteren dan portefeuilles van ondernemingen met lage scores. Deze resultaten veranderen niet na correctie voor marktrisico, beleggingsstijlen en sectoreffecten. Een beleggingsstrategie gericht op het aankopen van aandelen van eco-efficiënte bedrijven en het verkopen van inefficiënte bedrijven levert historische rendementsverschillen op van 6\% per jaar die ook na transactiekosten nog interessant zijn voor institutionele beleggers. Bovendien blijkt uit deze onderzoeken dat ondernemingen met een hoge eco-efficiëntie score relatief winstgevender zijn en hoger gewaardeerd op de beurs in termen van Tobin's q. In het proefschrift van mijn collega Jeroen Derwall (2007) wordt voorts aangetoond dat financiële markten vaker positief verrast worden door de winstcijfers van ondernemingen meteen eco-efficiënte bedrijfsvoering. Dewinsten van die ondernemingen blijken systematisch hoger dan de winstvoorspellingen van analisten die deze bedrijven continue screenen op overwegend financiële kengetallen. Deze resultaten zijn een eerste vingerwijzing dat analisten en beleggers het thema nog niet massaal hebben opgepikt. Zou dat immers wel het geval zijn, dan zouden analisten en beleggers deze informatie al verwerkt hebben in de geprognosticeerde winstcijfers en vervolgens gedisconteerd in de koers van het aandeel.

In moderne ondernemingen wordt steeds meer aandacht geschonken aan de toegevoegde waarde van goed personeelsbeleid (S). Laten we het voorbeeld van een financiële instelling beschouwen. Een bank of verzekeringsmaatschappij investeert in haar productieproces nauwelijks in kapitaalgoederen als machines en fabrieken. Een relatief groot deel van haar investeringen vindt plaats in menselijk kapitaal en de 
reputatie van de onderneming. Dat verklaart de enorme energie die financiële instellingen stoppen in traineeprogramma's en uitgekiende marketingcampagnes. Maar hoe waarderen financiële economen deze investeringen? En heeft deze inschatting voorspellende waarde voor de prestaties van die banken? Een kwalitatief en hoogstaand personeelsbestand als gevolg van een uitgekiend beleid draagt volgens Edmans (2007) bij aan de innovatiekracht van een onderneming en zal uiteindelijk ook de financiële prestaties van de onderneming in positieve zin beïnvloeden. In een recent onderzoek documenteert hij de mogelijke voordelen voor beleggers in aandelen van ondernemingen met tevreden werknemers. Fortune Magazine houdt jaarlijks een enquête onder werknemers om vast te stellen welke bedrijven de meest tevreden werknemers in dienst hebben: "Fortune list of best companies to work for". Een portefeuille van ondernemingen met een hoge notering in de Fortune lijst behaalde een rendement dat na risicocorrectie twee keer zo hoog was als dat van de aandelenmarkt als geheel. Edmans concludeert dat aandelenmarkten ogenschijnlijk (nog) niet in staat zijn om dit soort immateriële informatie goed te verwerken in de beurskoers. Het gevolg is dat de markt regelmatig wordt verrast in positieve of negatieve zin. Dat is zelfs het geval als de resultaten publiek bekend zijn²3.

Wetenschappelijk onderzoek naar de effecten van de kwaliteit van het ondernemingsbestuur op de financiële prestaties van ondernemingen heeft een rijkere historie ${ }^{24}$. De meeste studies richten zich op het effect van corporate governance $(G)$ indicatoren op respectievelijk aandelenrendementen, de waardering van ondernemingen op de beurs en boekhoudkundige winstbegrippen. Pensioenfondsen zijn als lange termijn beleggers bij uitstek geïnteresseerd in de invloed van de kwaliteit van bestuur op de financiële prestaties van ondernemingen op lange termijn. Helaas heeft slechts een beperkt aantal studies een dergelijk lange horizon. Een uitzondering is het onderzoek van Gompers, Ishii en Metrick (2003). De auteurs hadden de beschikking over een voldoende grote steekproef (plusminus 1500 beursgenoteerde ondernemingen in de Verenigde Staten) met een historie van ruim 10 jaar. In dit vaak geciteerde onderzoek analyseren zij de mogelijke invloed van beschermingsconstructies op aandelenrendementen. Een onderneming met een uitgebreid beschermingsmechanisme kan niet eenvoudig worden overgenomen. Het management van een dergelijke onderneming heeft daardoor relatief veel vrijheidsgraden. Dat kan ten koste gaan van de positie van aandeelhouders in die onderneming. 
Talloze studies tonen aan dat managers gebruik zullen maken van deze vrijheid om zichzelf te verrijken, bijvoorbeeld door "empire building" of buitensporige beloningspakketten en speciale regelingen. Na correctie voor risico blijkt dat portefeuilles van ondernemingen met relatief weinig beschermingsconstructies in de periode 1990-1999 jaarlijks maar liefst $8,5 \%$ meer rendement behaalden dan portefeuilles van ondernemingen met relatief veel beschermingsconstructies. De disciplinerende werking van de mogelijkheid dat de onderneming kan worden overgenomen bij slecht functioneren had blijkbaar een gunstige invloed op financiële prestaties van de onderneming. Bovendien zijn onbeschermde ondernemingen doorgaans hoger gewaardeerd op de beurs en hebben zij gemiddeld hogere winstmarges en boekhoudkundige rendementen op het eigen vermogen. Soortgelijke onderzoeken in Europa en Japan van respectievelijk Bauer, Guenster en Otten (2004) en Bauer, Frijns, Otten en Tourani Rad (2008) documenteren vergelijkbare resultaten.

Recent onderzoek van Core, Guay en Rusticus (2006) toont aan dat de informatie met betrekking tot goed ondernemingsbestuur voor een groot deel verwerkt lijkt te zijn in aandelenkoersen. Bovendien argumenteren zij dat een groot deel van het rendement van de strategie gebaseerd op Gompers et al. (2003) te verklaren is door de internethype in de jaren negentig. Wanneer zij de analyse van Gompers et al. herhalen, maar technologieaandelen buiten beschouwing laten, zijn de positieve resultaten vele malen kleiner en statistisch insignificant. Cremers en Nair (2005) doen daar nog een schepje bovenop door aan te tonen dat de resultaten nogal gevoelig zijn voor de procedure van de portefeuilleconstructie.

Een andere mogelijkheid om te toetsen of en hoe extrafinanciële informatie door financiële markten wordt verwerkt, is om het gedrag van beleggers en ondernemingen op financiële markten in kaart te brengen door enquêtes en experimenten. Een vaak geciteerde studie van McKinsey (2002) geeft bijvoorbeeld aan dat $80 \%$ van de institutionele beleggers bereid is om een fikse premie te betalen voor aandelen van goed bestuurde ondernemingen. Kunnen we dezelfde ontwikkeling verwachten met betrekking tot extrafinanciële informatie op het gebied van "E" en "S"? ECCE heeft in 2007 een aantal enquêtes onder Europese institutionele beleggers, analisten en ondernemingen gehouden. Aan de deelnemers werd gevraagd welke elementen uit een verzameling van ESG-factoren relevant zijn voor het besluit om al of niet te beleggen 
in ondernemingen. Wat bleek is dat analisten ondernemingen vooral screenen op corporate governance en in mindere mate op ethische, sociale en milieuaspecten. Hoewel institutionele beleggers informatie over de corporate governance van ondernemingen eveneens relatief het belangrijkst achten, vragen ze in toenemende mate om integratie van ethische, sociale en milieu-informatie in fundamentele bedrijfsanalyses. Uit de enquête blijkt duidelijk dat brokers op dit moment niet in deze behoefte kunnen voorzien ondanks de ondertekening van de Principles voor Responsible Investing door een groot deel van hun klanten. Een recent onderzoek van Mercer Investment Consultants (2007a) documenteert dat ook pensioenfondsen in de Verenigde Staten ESGfactoren in toenemende mate integreren in hun beleggingsproces en het aanbod van financiële producten.

De algemene conclusie die we kunnen trekken op basis van enquêtes is dat institutionele beleggers corporate governance tegenwoordig wel degelijk integreren in hun beleggingsproces. Het is dan ook niet verwonderlijk dat deze vorm van extrafinanciële informatie in de loop van de tijd wordt opgenomen in beurskoersen en -waarderingen. Het ligt daarom niet voor de hand dat een eenvoudige strategie als louter het kopen van goed geleide ondernemingen in de komende jaren nog zijn vruchten zal afwerpen. Veeleer zullen onverwachte veranderingen in de kwaliteit van het bestuur van ondernemingen de rendementen en risico's van deze beleggingen beïnvloeden. Beleggers zullen hierop moeten anticiperen of zelf in discussie moeten gaan met ondernemingen om ze te veranderen. De strategische vraag die resteert voor een institutionele belegger is wat er zal gebeuren met de verwerking van informatie op het gebied van milieu- en personeelsbeleid. Zullen beleggers constateren dat deze vaak immateriële informatie relevant is voor de winstgevendheid en het risico van de onderneming? Zo ja, dan zal dit mogelijk tot uitdrukking komen in de prijs die beleggers bereid zijn om te betalen: de beurskoers. Mogelijk is er dan sprake van een tijdelijk early mover advantage, maar na verloop van tijd zal de markt de in haar ogen relevante informatie hebben opgenomen. Heeft verantwoord beleggen een beperkte houdbaarheidsdatum?

De empirische studies richten zich voornamelijk op de invloed van ESGfactoren op het aantrekken van eigen vermogen door ondernemingen. Ondernemingen hebben echter doorgaans ook behoefte aan het aantrekken van vreemd vermogen tegen zo laag mogelijke kosten. 
Interessant is daarom de toegenomen aandacht voor extrafinanciële informatie in de op 1 januari 2007 in werking getreden internationale richtlijn Basel II. Het kapitaalakkoord stimuleert banken om verfijndere methoden te hanteren om de risico's van leningen door banken aan bedrijven in kaart te brengen. Het directe gevolg is dat banken een beter inzicht krijgen in de individuele risico's van ondernemingen waaraan geld wordt geleend. Uiteindelijk kan dit consequenties hebben voor de hoogte van de rente die ondernemingen moeten betalen aan banken. In het Basel II akkoord wordt onder meer expliciet gewezen op operationeel risico en reputatierisico ${ }^{25}$. Voorbeelden van operationeel risico zijn claims van het personeel vanwege onveilige arbeidsomstandigheden en daarmee gepaard gaande boetes van toezichthouders en acties van de vakbonden. Basel II schenkt na de boekhoudschandalen aan het begin van deze eeuw ook ruimschoots aandacht aan reputatierisico. Zeker voor banken is een goede reputatie een absolute noodzaak om goed te kunnen opereren. Leningen aan ondernemingen die plotseling in de problemen zijn gekomen door boekhoud- of milieuschandalen kunnen grote gevolgen hebben voor het vertrouwen van consumenten, kredietverleners, en toezichthouders in de bank die de lening heeft verstrekt. De vraag is echter of dergelijke risico's goed gemeten kunnen worden en zo ja, of er daadwerkelijk vermogen voor gereserveerd moet worden. Feit is dat banken in toenemende mate rekening houden met dit type informatie bij de bepaling van de rente voor bedrijfsleningen. Dat betekent dat beleggers in bedrijfsobligaties dit zullen moeten meewegen om een goed beeld te kunnen vormen van de rendementen en risico's van een dergelijke belegging.

De bovenstaande voorbeelden geven aan dat een belegger door het bewust integreren van extrafinanciële informatie een betere inschatting kan maken van de hoogte en de volatiliteit van de kasstromen van een onderneming. Het is echter van belang te beseffen dat deze informatie naar verwachting slechts een beperkt deel van de kasstromen zal verklaren. Niet elk stuk extrafinanciële informatie in het spectrum van ESG-factoren is even relevant. De koers van een aandeel wordt voor het grootste deel verklaard door de winstgevendheid van ondernemingen die wederom een functie is van de kwaliteit van het management, de innovatiekracht, de operationele efficiency en de vooruitzichten voor de sector waarin de onderneming actief is op lange termijn en andere, soortgelijke indicatoren. 
Ik concludeer door op te merken dat op basis van de huidige wetenschappelijke literatuur geen eenduidig beeld kan worden geschetst over welke factoren relevant zijn voor een belegger en welke niet. Voor- en tegenstanders kunnen altijd wel een studie citeren die hun gedachtegoed bevestigt. Het is de verantwoordelijkheid van een moderne portefeuillemanager om de steeds groter wordende stroom aan informatie over ondernemingen op zijn merites te beoordelen.

\section{Werk aan de winkel}

ECCE wil graag bijdragen aan de discussie over maatschappelijk verantwoord ondernemen en verantwoord beleggen. Door de oprichting van een platform voor fundamenteel onderzoek naar de rol van financiële markten in duurzame ontwikkeling draagt ECCE bij aan verdieping van de discussie over verantwoord beleggen. Medewerkers van ECCE schuwen daarbij de discussie met financiële marktpartijen niet. We leggen onze onderzoeksideeën informeel en formeel voor aan institutionele beleggers die worstelen met de uitvoering van verantwoord beleggen in de praktijk. Sinds de oprichting van het instituut hebben medewerkers van ECCE hun onderzoeksresultaten voorgelegd aan pensioenfondsen, banken en vermogensbeheerders uit Nederland, Zweden, Australië, Canada, Japan, Frankrijk en Noorwegen. Ook toezichthoudende instanties, de politiek en niet in de laatste plaats de schrijvende pers zijn zeer geïnteresseerd in ons onderzoek. ECCE mag tevreden zijn met de belangstelling en steun van gerenommeerde partijen als APG, PGGM, Nomura, Deutsche Bank Advisors, Dexia, Fortis Investments, GMI, Innovest Strategic Value Advisors en enkele andere financiële marktpartijen. Toch staan we wat mij betreft pas aan het begin van een werkelijk substantiële bijdrage van ECCE aan de discussie over de noodzaak of wenselijkheid van verantwoord beleggen. Ik identificeer in deze paragraaf enkele noodzakelijke voorwaarden voor een significante sprong vooruit in de komende jaren en geef aan welke rol ECCE daarin hoopt te gaan spelen.

Hetonderzoeksgebiedzougebaatzijn bijeen hogeresamenwerkingsgraad tussen wetenschappers van verschillende vakgebieden binnen de economische faculteit. ECCE heeft haar anker uitgeworpen in de sectie Financiering van de Universiteit Maastricht, maar staat open voor samenwerking over de grenzen van de vakgroep heen. Op dit moment werkt ECCE reeds samen met Accounting en Informatie Management 
en vinden de eerste ideeënuitwisselingen plaats met wetenschappelijke medewerkers van de sectie Marketing. Daarnaast is ECCE samen met de Zweedse universiteiten van Götheborg en Umeå onderdeel van een onderzoeksconsortium dat gesteund wordt door MISTRA, een Zweedse stichting ter bevordering van duurzame ontwikkeling. Er zijn echter ook duidelijke aanknopingspunten voor samenwerking met andere vakgroepen in onze eigen economische faculteit. Ik denk dan bijvoorbeeld aan wetenschappers die geïnteresseerd zijn in de microeconomische aspecten van maatschappelijk verantwoord ondernemen, maar ook aan collega's uit het vakgebied managementwetenschappen en arbeidspsychologie. Eind september van dit jaar organiseert ECCE samen met de PRI en de Verenigde Naties een tweedaagse conferentie met wetenschappers uit alle delen van de wereld. Het doel van die conferentie is dat instituten die onderzoek doen op het thema verantwoord beleggen en maatschappelijk verantwoord ondernemen elkaar informeren en gezamenlijk brainstormen over de inhoud van de onderzoeksagenda voor de komende jaren. Verder zullen we inventariseren hoe deze instituten met elkaar kunnen samenwerken om dit te bereiken. Ik nodig geïnteresseerde collega's van harte uit om deel te nemen aan dit initiatief.

Ten tweede dient de onderzoeksagenda verbreed en verdiept te worden. Te veel aandacht wordt geschonken aan empirisch onderzoek en te weinig aan een solide theoretische onderbouwing van de resultaten. Sceptische beleidsmakers en portefeuillemanagers zullen op basis van eclectische onderzoeksdossiers nauwelijks overtuigd raken van de toegevoegde waarde van de integratie van extrafinanciële informatie. Natuurlijk zullen zij ook moeten openstaan voor het debat, maar wetenschappers zullen eerst duidelijk moeten maken via welk mechanisme extrafinanciële grootheden bijdragen aan de waarde van de onderneming. Om dit te bewerkstelligen dienen onderzoekers niet louter in te zoomen op de relatie van ESG-factoren met rendementen en waarderingen op de beurs. De afstand tussen beide variabelen is als het ware te groot. Koersveranderingen komen ceteris paribus tot stand door veranderingen in de ingeschatte hoogte en volatiliteit van kasstromen van de onderneming. Die grootheden worden onder andere beïnvloed door consumentengedrag, het gedrag van concurrenten, internationale wetgeving en veranderende voorkeuren van beleggers. De vraag of ratinginstituten in de huidige vorm zinvol kunnen bijdragen aan deze zoektocht is wat mij betreft niet zo eenvoudig te beantwoorden. Het 
verwerken van ratinginformatie zonder daarbij de onderliggende criteria goed te bestuderen heeft mijns inziens weinig zin. Portefeuillemanagers en analisten dienen de details van de informatie tot zich te nemen en vervolgens op grond hiervan een zelfstandige inschatting te maken. Hetzelfde geldt voor wetenschappers die deze data gebruiken in hun onderzoeken.

Voorts is nauwe samenwerking met medewerkers van andere faculteiten en vakgebieden een vereiste voor het maken van een significante stap vooruit. Veel van de vragen die een portefeuillemanager moet beantwoorden zijn onlosmakelijk verbonden met vragen die zijn kennisgebied als financieel econoom ruimschoots overstijgen. Hoe kan bijvoorbeeld de emissie van $\mathrm{CO}_{2}$ objectief gemeten worden? Zinvol onderzoek naar de energie-effecten van gebouwen moet gebaseerd zijn op objectieve maatstaven die niet ter discussie staan. Welke gedragsaspecten beïnvloeden kopers bij de aanschaf van verantwoorde beleggingsproducten? Beleggers in dergelijke producten lijken trouwer te zijn dan het gemiddelde, zie Bollen (2007). Hoe beperkt de wetgeving in de Europese Pensioenrichtlijn een pensioenfonds bij de keuze voor een verantwoord beleggingsbeleid? Het spreekt voor zich dat de inbreng van onder andere milieuwetenschappers, psychologen en juristen meer dan gewenst is. Mijn collega Pim Martens en ik brainstormen regelmatig over samenwerking tussen ECCE en ICIS. Hopelijk kunnen we onze ideeën in de komende tijd concreet invullen.

Om kritische studenten af te kunnen leveren die openstaan voor een discussie over maatschappelijk verantwoord ondernemen en beleggen, is het noodzakelijk dat het vakgebied nadrukkelijker wordt geïntegreerd in het curriculum van studenten. Enkele vakgroepen in de economische faculteit verwerken het thema sporadisch in een verdwaalde taak of opdracht. Ik mijmer echter over een verplichte minor voor alle studenten van de Universiteit Maastricht, ongeacht faculteit of studierichting en aangeboden door medewerkers van alle faculteiten. Tot die tijd verwerk ik het thema in mijn eigen onderwijsaanbod. Niets vermoedend zullen studenten Institutionele Beleggers - toekomstige portefeuillemanagers en analisten - geconfronteerd worden met het thema verantwoord beleggen.

Wetenschappelijk onderzoek naar verantwoord beleggen dient meer dan voorheen gericht te worden op andere beleggingscategorieën dan 
aandelen alleen. Pensioenfondsen beleggen in de praktijk vaak meer dan de helft van hun vermogen in onroerend goed en vastrentende waarden. Het gros van de publicaties op het gebied van verantwoord beleggen richt zich echter op beleggingen in aandelen. Het directe gevolg is dat de integratie van extrafinanciële informatie in die categorieën ver achterblijft bij de ontwikkelingen in het aandelendomein. Er zijn enkele goede voorbeelden van studies op het gebied van bedrijfsobligaties en vastgoed. Recent is er bijvoorbeeld aandacht besteed aan de relatie tussen beschermingsconstructies en bedrijfsobligaties ${ }^{26}$. Hieruit blijkt dat verschaffers van vreemd vermogen lagere spreads, dus lagere risicopremies, eisen bij de aanwezigheid van beschermingsconstructies, terwijl deze vehikels door aandeelhouders juist als negatief worden ervaren, aldus Gompers et al. (2003). Het interessante feit doet zich voor dat pensioenfondsen in de praktijk zowel aandelen als bedrijfsobligaties van dezelfde onderneming bezitten. Een effectief engagementbeleid zou hiermee expliciet rekening moeten houden. Onderzoek naar de relatie tussen de spreads op bedrijfsobligaties en andere ESG-factoren staat nog in de kinderschoenen, maar staat nadrukkelijk op de onderzoeksagenda van ECCE.

Ook de impact van extrafinanciële informatie op vastgoed is nauwelijks onderzocht. ECCE heeft dit thema recent opgepakt in twee lopende onderzoeken. De studie van Bauer, Eichholtz en Kok (2007) bestudeert genoteerde vastgoedfondsen. Het management van die fondsen is verplicht om nagenoeg alle vrije kasstromen uit te keren aan de aandeelhouders van het fonds. Dit impliceert dat deze managers relatief weinig speelruimte hebben om waarde ten koste van aandeelhouders van aandeelhouders naar zich toe te trekken. Uit het onderzoek blijkt dat de waardering en de winstgevendheid van deze vastgoedfondsen niet samenhangen met de bijbehorende governance scores. De tweede ECCE studie van Eichholtz, Kok en Quigley (2008) stelt zich de vraag of duurzame kantoorgebouwen, ironisch genoeg staat de stad New York vol met dergelijke gebouwen, hogere huren zouden kunnen opleveren dan conventionele kantoorgebouwen. Dat blijkt inderdaad het geval: huurders zijn bereid om $6 \%$ meer huur te betalen dan voor een vergelijkbaar kantoorgebouw. Maar ook hier is de cruciale vraag: verdien je met deze additionele huur de mogelijk hogere bouwkosten terug? De parallellen met beleggingen in aandelen zijn duidelijk lijkt mij. 
Eenlaatstevoornemen is om meeraandachtteschenken aanengagement. Aandeelhouders worden steeds mondiger. Dat uit zich onder andere in gecoördineerd stemgedrag op aandeelhoudersvergaderingen. Institutionele beleggers stemmen vooral op thema's die te maken hebben met corporate governance. Voorbeelden hiervan zijn certificering van aandelen en de beloning van bestuurders. Er is nog betrekkelijk weinig wetenschappelijk onderzoek verricht naar de effectiviteit van die engagementactiviteiten. Leidt de druk van beleggers op lange termijn tot verbetering bij de onderneming en heeft dat positieve consequenties voor de financiële prestaties van de targetonderneming op lange termijn ${ }^{27}$ ? In toenemende mate vindt ook beïnvloeding plaats op het terrein van sociale, ethische en milieuaspecten. Ik zou graag willen toetsen of de opbrengsten, al of niet gemeten in financiële termen, opwegen tegen deze investeringen. ECCE is om die reden voornemens om in samenwerking met de Universiteit van Tilburg een grootschalige enquête op het gebied van verantwoord ondernemen en beleggen in te richten. Hierbij zullen beleggers, ondernemingen, consumenten en deelnemers van pensioenfondsen betrokken zijn. Op die manier kan ECCE veranderende inzichten en preferenties documenteren in de tijd.

\section{Ziedaar!}

Is het thema verantwoord beleggen een hype of zal het op lange termijn bijdragen aan beter werkende kapitaalmarkten? Ik kan het u vandaag nog niet vertellen. Het kenmerk van een echte hype is dat deze uitdooft na een korte periode van veel aandacht. Feit is echter dat verantwoord beleggen al jaren in de belangstelling staat van een groot aantal spelers op financiële markten. Toch kleeft er nog steeds iets vluchtigs aan het thema. Voor een deel is dat omdat de meerderheid van de beleggers pas net met het fenomeen heeft kennisgemaakt. Een andere verklaring is dat er nog steeds geen duidelijke theoretische onderbouwing is waarom verantwoord beleggen waarde zou kunnen toevoegen in een kapitalistisch georganiseerde maatschappij als de onze. Volop kansen dus voor wetenschappers die in dit onontgonnen terrein duiken.

In mijn betoog vandaag heb ik twee basisvormen besproken: uitsluiting en verantwoord beleggen als kans. In de financiële literatuur is intussen veel aandacht voor de invloed van uitsluiting op de efficiëntie van aandelenportefeuilles. Uit meerdere onderzoeken blijkt dat drastische uitsluiting zal leiden tot nutverlies voor beleggers. Ook blijkt dat een 
weloverwogen en beperkt uitsluitingsbeleid geen probleem hoeft te zijn. De deelnemers van Nederlandse pensioenfondsen hoeven zich dus geen zorgen te maken dat hun pensioenen worden aangetast. Het uitsluitingsbeleid van pensioenfondsen beperkt zich doorgaans tot een klein aantal ondernemingen. De gevolgen voor rendement en risico van de portefeuille zijn dus naar verwachting verwaarloosbaar. Biedt het thema verantwoord beleggen ook kansen voor portefeuillemanagers van pensioenfondsen, verzekeraars en beleggingsfondsen? Moeten zij hun informatieset uitbreiden met informatie over ESG-factoren? Of is dat pure tijdverspilling? Wetenschappelijk onderzoek geeft hier en daar enkele concrete aanwijzingen dat extrafinanciële informatie kan bijdragen aan een goede inschatting van het risico en rendement van een onderneming. Helaas is de theoretische onderbouwing nog niet goed uitgerijpt in de literatuur. Elk goedbedoeld empirisch onderzoek zal om die reden minder serieus genomen worden dan het mogelijk verdient. Om die stap voorwaarts te maken dient de extrafinanciële informatie op een lager aggregatieniveau te worden bestudeerd en niet alleen in relatie tot beurskoersen en -waarderingen. Volop ruimte voor samenwerking met andere vakgebieden dus. ECCE zal deze handschoen oppakken.

Zelfs als men het er over eens is dat de integratie van sommige ESGfactoren zinvol is, blijft de vraag relevant of deze informatie al is verwerkt in aandelenkoersen. De voorbeelden over milieumanagement en menselijk kapitaal klinken heel plausibel, maar mogelijk integreren portefeuillemanagers en financiële analisten deze ESG-factoren al in hun analyse van ondernemingen. Voor een deel zal dat het geval zijn, maar de studies over beschermingsconstructies, eco-efficiëntie en de Fortune lijst zouden dan geen significante resultaten mogen vinden. Blijkbaar wordt een deel van de ESG-informatie nog niet helemaal opgepikt door financiële markten. We moeten echter oppassen met deze redenering vanwege het mogelijke "file drawer" probleem. Mijn aanbeveling aan portefeuillemanagers en analisten is heel concreet: neem ESG-informatie mee bij het samenstellen van de portefeuille. Let vooral op informatie over het personeelsbeleid van de onderneming.

Een deel van de ESG-factoren zal niet relevant zijn voor beleggers omdat het niet geprijsd wordt op financiële markten of omdat de informatie van dusdanig lage kwaliteit is dat ze genegeerd kan worden door beleggers. Ratinginstituten hebben een belangrijke taak om positief bij te dragen 
aan de ontwikkeling van verantwoord beleggen. Te veel instituten helpen beleggers bij het operationaliseren van het uitsluitingsbeleid en te weinig bij het ontdekken van kansen van verantwoord beleggen. Dat moet veranderen om het debat tussen voor- en tegenstanders scherp te kunnen voeren. Alarmerend is in dat licht dat sommige onafhankelijke leveranciers opgekocht worden door grote financiële marktpartijen. Wordt de informatie dan nog wel onafhankelijk verzameld?

In dit betoog stonden pensioenfondsen centraal. Hun speciale plaats in Nederland polderland dwingt hen om voorlopers te zijn in de maatschappelijke discussie over verantwoord beleggen. Op enkele uitzonderingen na doen verzekeraars en beleggingsfondsen nauwelijks mee in dat debat. Dat zal moeten veranderen en dat kunt alleen $u$ als consument van financiële producten en diensten bewerkstelligen. Vraag gerust aan uw tussenpersoon of beleggingsadviseur naar het beleid en de kosten van beleggingsproducten. Als institutionele beleggers serieus genomen willen worden door ondernemingen waarin ze beleggen, dienen ze ook hun eigen maatschappelijke verantwoordelijkheid beter in te vullen. Het palmares van dynamisch uitsluiten, mijn vertaling van actief beleid, is immers verre van indrukwekkend.

In dat licht is het interessant dat ik enkele weken geleden een brief ontving van Fortis ASR waarin vermeld stond dat het gespaarde bedrag dat mijn vrouw en ik recentelijk ontvingen op een beleggingsverzekering - een zogenaamd ABC spaarplan - mogelijk aangepast gaat worden. Als de kosten van de polis hoger zijn dan toegestaan in de richtlijnen van de nationale ombudsman volgt mogelijk een fikse nabetaling. Is het toeval dat ik deze brief enkele weken voor mijn redevoering krijg? Waarschijnlijk wel, maar ik beloof $u$ dat ik de wantoestanden in de financiële sector waar $u$ en ik gemerkt en ongemerkt de dupe van zijn zal blijven onderzoeken in mijn functie als hoogleraar institutionele beleggers. 


\section{Dankwoord}

Dames en heren, aan het einde van mijn betoog wil ik $u$ graag bedanken voor uw aanwezigheid. Ik sluit af met een dankwoord.

Leden van het College van Bestuur en het bestuur van de Faculteit der Economische Wetenschappen en Bedrijfskunde. Ik waardeer uw steun voor mijn initiatieven zeer. De middelen die $u$ aan ECCE ter beschikking heeft gesteld, maken het mogelijk om de plannen die ik heb genoemd in mijn rede nog beter uit te voeren.

Collega's van de vakgroep Financiering. Velen van jullie ken ik al geruime tijd. Ik dank jullie voor de plezierige samenwerking in de afgelopen jaren. Ik heb erg veel plezier in het begeleiden van mijn promovendi Mathijs Cosemans, Rik Frehen, Daniel Hann, Robin Braun en Paul Smeets. Ik leer ook zelf ontzettend veel en waardeer de goede verstandhouding die ik met ieder van jullie heb. Jullie zijn al zeer succesvol in zelfstandig wetenschappelijk onderzoek. Ik ben ervan overtuigd dat jullie hier op deze plek binnen afzienbare tijd je proefschrift zullen verdedigen. Maar bedenk: afzienbaar is een rekbaar begrip. Els van Aernsbergen, dank je wel voor je geduld in de afgelopen maanden. Rogér Otten, ik ben je zeer dankbaar dat jij je tijdens de brainstormsessie met Kees zo sterk hebt gemaakt voor het thema verantwoord beleggen. Het eerste succesvolle onderzoek was voor een belangrijk deel jouw werk. Mijn collega Peter Schotman wil ik speciaal bedanken omdat hij zich enkele jaren geleden heeft ingezet voor de komst van de leerstoel Institutionele Beleggers.

Eccianen in enge zin: dus Rachel Campbell, Els van Aernsbergen, Nadja Günster, Harry Hummels, Paulo Peneda, Daniel Hann, Robin Braun, Piet Eichholtz, Nils Kok, Frank Moers en in het bijzonder Kees Koedijk en Jeroen Derwall. Wie had verwacht dat we ooit een instituut zouden oprichten dat zowel leidt tot uitstekende wetenschappelijke publicaties als tot veel aandacht in de media en de financiële sector? Zonder jullie bijdrage zou het nooit gelukt zijn. Ik hoop dat we in de komende jaren nog goed zullen samenwerken om ECCE te laten uitgroeien tot het kenniscentrum op het gebied van verantwoord beleggen. Over twee weken horen we of ECCE nog enkele jaren door het Zweedse onderzoeksinstituut zal worden gesteund. Duimen jullie met mij mee? 
Ex-collega's van ABP en APG. Toen ik in 1995 bij ABP Vermogensbeheer ging werken, fronsten nogal wat mensen hun wenkbrauwen. Wat had ik te zoeken bij een belegen overheidsorganisatie? Het tegendeel bleek waar. ABP was een organisatie in verandering en dan zijn er doorgaans veel kansen en mogelijkheden. Dat geeft mij ook in de positie van hoogleraar institutionele beleggers veel voordelen. Hoeveel hoogleraren kunnen terugkijken op een functie als fondsmanager van een aandelenportefeuille van ruim 30 miljard gulden? Die ervaringen geven mij inspiratie voor nieuw onderzoek en tegelijkertijd de mogelijkheid om wetenschappelijk onderzoek te nuanceren als het gewenst is. Een speciaal woord van dank zou ik willen uitspreken voor enkele collega's die mij in de ABP-periode zeer dierbaar waren en die mij geholpen hebben te geraken waar ik nu ben. Jean Frijns, Rene Maatman, Robbert Coomans, Tom Steenkamp en Roderick Munsters: het waren mooie jaren. Ik stel het zeer op prijs dat ik nog dagelijks de vruchten mag plukken van de intense samenwerking tussen ABP (of is het APG?) en de Universiteit Maastricht.

Lieve vrienden en vriendinnen. Sommigen van jullie hebben lang in de file gestaan om vandaag naar mij te luisteren. En jullie mogen niet eens een vraag stellen. Ik beloof jullie plechtig om voortaan ook heel goed naar jullie te luisteren. Geniet dus van een welverdiend drankje en hapje en van de mooie stad Maastricht.

Pa en ma, ik realiseer mij dat ik mijn eerste beleggingsadvies ooit aan jullie heb gegeven. Het was een onvervalst staaltje van onverantwoord beleggen. Ik adviseerde jullie om het bedrijf HCS Technology te kopen enkele maanden voor het bedrijf vrijwel haar volledige beurswaarde verloor door mismanagement. Ik was op dat moment net begonnen aan mijn studie economie en had achteraf gezien nogal last van overmatig zelfvertrouwen. Twintig jaar na dato welgemeende excuses. Zonder jullie steun en aansporingen had ik deze mijlpaal niet bereikt. Dit is dus ook de kroon op jullie werk.

Gijs, Joppe en Mees. Goed dat jullie het zo lang hebben volgehouden vanmiddag en dat jullie niet al te hard gelachen hebben over pappa in zijn rare jurk. Pappa was de afgelopen maanden nogal eens druk bezig in zijn werkkamer op tijden dat jullie graag met hem zouden spelen. En af en toe was ik er wel, maar eigenlijk toch ook weer niet. Dat gaat gelukkig snel weer veranderen. De zomervakantie komt eraan en dan gaan we 
lekker veel plezier maken in Zuid-Frankrijk.

Suzanne, de laatste woorden van vandaag zijn natuurlijk bestemd voor jou. Ik heb zo veel aan jou te danken. Steeds als ik weer eens op reis ging voor mijn werk of als er een deadline naderde, hield jij ons gezin efficiënt draaiende. Je hebt heel wat moeten opofferen de afgelopen jaren. De volgende uitdaging gaan we gelukkig samen aan: een avontuur in Nieuw-Zeeland. Vier maanden met ons vijven in een mooie omgeving aan de andere kant van de wereld om terug te kijken op de afgelopen tijd en vooruit te kijken naar hopelijk nog vele mooie jaren. Dank je wel.

Ik heb gezegd. 


\section{Referenties}

Angel, J. and P. Rivoli (1997), “Does Ethical Investing Impose a Cost Upon the Firm? A Theoretical Perspective", Journal of Investing, Winter, pp. 57-61.

Anginer, D., K. Fisher and M. Statman (2008), "Stocks of Admired Companies and Despised Ones", Working Paper, University of Santa Clara.

Bauer, R., J. Derwall and W. Jaworski (2007), "Extra-financial Information in Financial Communication of European Companies", ECCE Report, Maastricht University, www.corporate-engagement.com.

Bauer, R., P. Eichholtz and N. Kok (2007), "Corporate Governance and Performance: The REIT effect", ECCE Working Paper, Maastricht University, www.corporateengagement.com.

Bauer, R., P. Frentrop, N. Günster and H. de Ruiter (2004), “Corporate Governance: A Review of the Debate in The Netherlands and Empirical Evidence on the Link with Financial Performance", VBA Journaal, 20:4, pp. 19-34.

Bauer, R., B. Frijns, R. Otten and A. Tourani Rad (2008), "The Impact of Corporate Governance on Corporate Performance: Evidence from Japan”, Pacific Basin Finance Journal, 16, pp. 236-251.

Bauer, R., N. Günster and R. Otten (2004), "Empirical Evidence on Corporate Governance in Europe: The Effect on Stock Returns, Firm Value and Performance", Journal of Asset Management, 5:2, pp. 91-104.

Bauer, R., C.G. Koedijk and R. Otten (2005), "International Evidence on Ethical Mutual Fund Performance and Investment Style", Journal of Banking and Finance, 29, pp. $1751-1767$.

Bello, Z.Y. (2005), "Socially Responsible Investing and Portfolio Diversification", Journal of Financial Research, 28, pp. 41-57.

Bollen, N.P. (2007), "Mutual Fund Attributes and Investor Behavior", Journal of Financial and Quantitative Analysis, 42:3, pp. 683-708.

Chatterji, A. and D. Levine (2006), "Breaking Down the Wall of Codes: Evaluating Non-Financial Performance Measurement", California Management Review, 48:2, pp.29-51. 
Core, J., W. Guay and T. Rusticus (2006), "Does Weak Governance Cause Weak Stock Returns? An Examination of Firm Operating Performance and Investors' Expectations", The Journal of Finance, 61, pp. 655-687.

Council on Ethics for the Government Pension Fund - Global (2006), Annual Report, Oslo.

Cremers, M. and V. Nair (2005), "Governance Mechanisms and Equity Prices", The Journal of Finance, 6o, pp. 2859-2894.

Cremers, M., V. Nair and J. Wei (2007), "Governance Mechanisms and Bond Prices", The Review of Financial Studies, 20, pp. 1359-1388.

Crouhy, M., D. Galai and R. Mark (2006), "The Essentials of Risk Management", McGraw-Hill Companies, inc.

Derwall, J., N. Günster, R. Bauer and C.G. Koedijk (2005), "The Eco-Efficiency Premium Puzzle", Financial Analysts Journal, 61:2, 2005, pp. 51-63.

Edmans, A. (2007), "Does the Stock Market Fully Value Intangibles? Employee Satisfaction and Equity Prices", Working Paper, Wharton School.

Eichholtz, P., N. Kok and J. Quigley (2008), “Doing Well By Doing Good? Green Office Buildings", ECCE Report, Maastricht University, www.corporate-engagement.com.

Fama, E.F. and K. French (1993), “Common Risk Factors in the Returns on Stocks and Bonds", Journal of Financial Economics, 33, pp. 3-56.

Friedman, M. (1970), "The Social Responsibility of Business is to Increase its Profits", The New York Times Magazine, September 13th, New York.

Friend White, C.F. (2005), "SRI Best Practices: Learning from the Europeans”, Journal of Investing, Fall, pp. 88-93.

Galema, R., A. Plantinga and B. Scholtens (2008), "Diversification of Socially Responsible Investment Portfolios: Testing for Mean-Variance Spanning”, Working Paper, University of Groningen.

Geczy, C., R.F. Stambaugh and D. Levin (2005), "Investing in Socially Responsible Mutual Funds", Working Paper, University of Pennsylvania. 
Gompers, P., J.L. Ishii and Metrick, A. (2003), "Corporate Governance and Equity Prices”, Quarterly Journal of Economics, Vol. 188:1, 2003, pp. 107-155.

Grossman, B.R., and W. Sharpe (1986), "Financial Implications of South African Divestment”, Financial Analysts Journal, 42:4, 2005, pp. 15-29.

Gruber, M.J. (1996), "Another Puzzle: The Growth in Actively Managed Mutual Funds", The Journal of Finance, 51, pp. 783-810.

Günster, N., J. Derwall, R. Bauer, and C.G. Koedijk (2006), "The Economic Value of Corporate Eco-efficiency", ECCE Working Paper, Maastricht University, www. corporate-engagement.com.

Hawley, J. and A. Williams (2000), "The Rise of Fiduciary Capitalism”, University of Pennsylvania Press.

Henderson, D. (2002), "Misguided Virtue: False Notions of Corporate Social Responsibility", Institute of Economic Affairs.

Hong, H. and M. Kacperczyk (2007), "The Price of Sin: the Effect of Social Norms on Markets", Working Paper, Sauder School of Business.

Hummels, H. (2007a), “De Kracht van Pensioenfondsen”, ECCE Report, Maastricht University, www.corporate-engagement.com.

Hummels, H. (2007b), “De Gearriveerde Toekomst: Nederlandse Pensioenfondsen en de Praktijk van Verantwoord Beleggen”, Gezamenlijke uitgave van VB, OPF en UvB, Den Haag.

Hummels, H. and R. Bauer (2006), "Van Stille Kracht naar Stille Macht: Pensioenfondsen in Gesprek met Ondernemingen over Corporate Governance en Maatschappelijk Handelen", van Gorcum, Assen.

Jaworski, W. (2007), "The Use of Extra-financial Information by Research Analysts and Investment Managers", ECCE Report, Maastricht University, www.corporateengagement.com.

Jensen, M. (2001), "Value Maximization, Stakeholder Theory, and the Corporate Objective Function", Journal of Applied Corporate Finance, 14:3, pp. 8-21. 
Kempf, A. and P. Osthoff (2007), "The Effect of Socially Responsible Investing on Portfolio Performance", European Financial Management, 13:5, pp. 908-922.

Maatman, R. (2007), "Prudent-person-regel en verantwoord beleggingsbeleid", Tijdschrift voor Ondernemingsbestuur, 2007-6, pp. 177-187.

Malkiel, B.G. (1995), "Returns from Investing in Equity Mutual Funds from 1971 to 1991", The Journal of Finance, 50, pp. 549-572.

Margolish, J.D. and J.P. Walsh (2001), "People and Profits? The Search for a Link Between Social and Financial Performance", Mahwah, NJ: Lawrence Erlbaum Associates.

McKinsey (2002), "Global Investor Opinion Survey”, www.mckinsey.com.

Mercer Investment Consultants (2007a), "Defined Contribution Plans and Socially Responsible Investing in the United States: a Survey of Plan Sponsors, Administrators and Consultants", www.mercer.com.

Mercer Investment Consultants (2007b), "Demystifying Responsible Investment Performance: A Review of Key Academic and Broker Research on ESG factors", UNEP FI and Mercer, October, www.mercer.com.

Merton, R. (1987), “A Simple Model of Capital Market Equilibrium with Incomplete Information", Journal of Finance, 42:3, pp. 483-510.

Milevsky, M., A. Aziz, A. Goss, J. Thomson and D. Wheeler (2004), "Cleaning a Passive Index: How to Use Portfolio Optimization to Satisfy CSR Constraints", SSRN Working Paper, December.

Munnell, A. H. (2007), "Should Public Pension Funds Engage in Social Investing?", Publication Center for Retirement Research, Boston.

Orlitzky, M., F. Schmidt and S. Rynes (2003), "Corporate Social and Financial Performance: a Meta-analysis", Organization Studies, 24:3, pp. 403-441.

Porter, M. and C. van der Linde (1995), "Green and Competitive, Ending the Stalemate", Harvard Business Review, September-October, pp. 120-135.

Porter, M. and C. van der Linde (1995), "Toward a New Conception of the 
Environment-Competitiveness Relationship", Journal of Economic Perspectives, 9:4, pp. 97-118.

Porter, M. and M. Kramer (2006), "Strategy and Society: The Link Between Competitive Advantage and Corporate Social Responsibility", Harvard Business Review, December, pp. 1-14.

Salaber, J. (2007), "The Determinants of Sin Stock Returns: Evidence on the European Market", Working Paper, DRM-CEREG.

Scargle, J.D. (2000), "Publication Bias: The File-Drawer Problem in Scientific Inference", Journal of Scientific Exploration, 14:1, pp. 91-106.

Schroeder, M. (2007), "Is There a Difference? The Performance Characteristics of SRI Equity Indices", Journal of Business Finance and Accounting, 34 (1\&2), pp. 331-348.

Zingales, L. (2000), "In Search of New Foundations", Journal of Finance, 55:4, pp. $1623-1652$.

\section{Noten}

1 Vgl. NRC Handelsblad van 25 maart 2002

2 Ditcitaat is afkomstig uit de Zembla documentaire "HetClusterbomgevoel", uitgezonden op 18 maart 2007.

3 Ik verwijs graag naar een citaat van Francis Bacon (in: The Advancement of Learning) dat Scargle (2000) aanhaalt in zijn studie naar het file drawer probleem: "It is human nature for the affirmative or active to effect more than the negative or privative. So that a few times hitting, or presence, countervails oft-times failing or absence."

4 Vgl. Catherine Friend White (2005), "SRI Best Practices: Learning from the Europeans", Journal of Investing, Fall, pagina 88.

5 Zie Het Financieele Dagblad van donderdag 17 april 2008, pagina 15 (“Votron wil open zijn over salaris").

6 Vgl.www.pggm.nl

7 Vgl. James Hawley en Andrew Williams: "The Rise of Fiduciary Capitalism".

8 Vgl. Harry Hummels (2007b).

9 De Vereniging van Bedrijfstakpensioenfondsen, de Stichting Ondernemingspensioenfondsen en de Unie van Beroepspensioenfondsen.

10 Vgl. www.asnbank.nl.

11 Voor meer details over het verantwoord beleggingsbeleid verwijs ik naar het jaarverslag 
van de Council on Ethics for the Government Pension Fund - Global, Annual Report 2006 (2006) en de ethical guidelines die gedownload kunnen worden van de website van Norges Bank Investment Management: www.nbim.no PFZW stelt uitdrukkelijk in haar Verklaring inzake de Beleggingsbeginselen dat verantwoord beleggen past bij de identiteit van het fonds en dat het beleggingsbeleid wordt afgestemd op de normen en waarden van zijn deelnemers. Het fonds stelt heel expliciet dat "financieel en maatschappelijk rendement samengaan", vgl. ABTN PFZW op website PFZW: www.pfzw.nl

13 Vgl. Maatman (2007).

14 Een ander voorbeeld heeft betrekking op de strategische beleggingskeuzes van pensioenfondsen. Enkele pensioenfondsen hebben intussen de beleggingscategorie grondstoffen in hun portefeuillesopgenomenomdatblijktuitwetenschappelijkonderzoek dat grondstoffen positief bijdragen aan de rendement- en risicokarakteristieken van de portefeuille als geheel. Indien een fonds grondstoffen bewust niet in zijn strategische beleggingsportefeuille heeft opgenomen, is deze beleidskeuze dan strijdig met de prudent-person-regel? Er wordt bij dat fonds mogelijk niet optimaal gebruik gemaakt van de diversificatiemogelijkheden, zeker niet als rekening wordt gehouden met de verplichtingen van het pensioenfonds. Wederom zijn er parallellen met het voorbeeld van ASN. Wat maakt dat de prudent-person-regel strikter lijkt te worden toegepast als het thema verantwoord beleggen en uitsluiting in het bijzonder ter sprake komt?

15 Het pure model van Merton (1987) geldt immers alleen als een significante groep beleggers een bepaald type ondernemingen negeert en als deze beleggers hierbij min of meer homogene criteria hanteren. In die setting vragen beleggers een risicopremie om deze ondernemingen aan te houden.

16 Een voorbeeld dat veel overeenkomsten met de voorgaande redenering is een recente studie van Anginer, Fisher en Statman (2008). Zij onderzochten of ondernemingen die hoog scoren op de "Fortune list of America's Most Admired Companies" ook goed presteren op de beurs. Het tegendeel is echter waar: aandelen van "admired companies" hebben lagere rendementen dan aandelen van "despised companies". De auteurs verklaren het verschil met een psychologische benadering: beleggers betalen graag met lage rendementen (overwaardering) om te kunnen beleggen in ondernemingen waar ze een goed gevoel van krijgen. Ondernemingen die beleggers graag links laten liggen zijn echter ondergewaardeerd en vertonen dus hogere rendementen op de beurs.

17 Salaber (2007) presenteert soortgelijke resultaten in Europa. Zij vindt ook dat het effect van normen op de risicopremie sterker is in landen met een overwegend protestantse bevolking.

18 In deze context is het interessant om te vermelden dat sommige beleggingsfondsen hierop inspelen. Het VICE Fund (www.vicefund.com) belegt alleen in ondernemingen die ik in dit betoog definieer als sin stocks. In de afgelopen vijf jaar heeft dit fonds ruim $8 \%$ per jaar beter gepresteerd dan de beurs als geheel. 
19 In die modellen wordt rekening gehouden met het feit dat een deel van het risico van een belegging afhankelijk is van de grootte van de onderneming en de waardering in termen van boekwaarde versus marktwaarde.

20 De meeste portefeuillemanagers ontvangen een bonus als hun portefeuille een hoger rendement behaalt dan de benchmark. Er volgt in veel gevallen geen correctie voor het risico dat de portefeuille gelopen heeft. Als uitgesloten ondernemingen inderdaad hogere rendementen behalen op de beurs omdat ze ondergewaardeerd worden en onderhevig zijn aan liquiditeitsrisico, dan is dit een extra motief voor portefeuillemanagers om niet mee te werken aan een uitsluitingsbeleid. Deze ondernemingen zijn een goede bron voor hun niet voor risico gecorrigeerde rendementen en dus hun bonus. De manier waarop portefeuillemanagers beloond worden zal dus van invloed zijn op de wijze waarop de discussie wordt gevoerd.

21 Vgl. Derwall et al. (2005) en Günster et al. (2006).

22 Een alternatieve definitie voor eco-efficiëntie is de hoeveelheid input (bijvoorbeeld grondstoffen) die nodig is om een bepaalde hoeveelheid output te produceren: inputoutput efficiëntie.

23 Kempf en Osthoff (2007) vinden soortgelijke resultaten gebruik makend van KLD, een van de oudste ratinginstituten op het gebied van maatschappelijk verantwoord ondernemen.

24 Vgl. Bauer, Frentrop, Günster en de Ruiter (2004) voor een overzicht van de literatuur.

25 Vgl. hoofdstuk 1 in Crouhy, Galai en Mark (2006).

26 Vgl. Cremers, Nair en Wei (2007).

27 Toch kan wel iets worden gezegd over de mogelijke effecten van engagement op de financiële performance van ondernemingen. Een aansprekend voorbeeld is het zogenaamde "CalPERS-effect". CalPERS publiceert al jaren een zwarte lijst met ondernemingen die in haar ogen slecht presteren op het gebied van de kwaliteit van bestuur: de zogenaamde "focus list of corporate laggards". De jaren voordat deze bedrijven op de lijst werden geplaatst, presteerden ze ver beneden het beursgemiddelde. In de jaren na de openlijke bekendmaking dat deze ondernemingen bij CaIPERS op de zwarte lijst staan, presteren ze ruim boven het gemiddelde. Kennelijk leidt deze vorm van engagement tot concrete resultaten. 

